\title{
DECLINING BUSINESS DYNAMISM AMONG OUR BEST OPPORTUNITIES: THE ROLE OF THE BURDEN OF KNOWLEDGE
}

\author{
Thomas Astebro \\ Serguey Braguinsky \\ Yuheng Ding
}

August 2020

The Institute of Social and Economic Research

Osaka University

6-1 Mihogaoka, Ibaraki, Osaka 567-0047, Japan 


\title{
Declining Business Dynamism among Our Best Opportunities: \\ The Role of the Burden of Knowledge
}

Thomas Åstebro, Serguey Braguinsky, Yuheng Ding*

August 2020

\begin{abstract}
We document that since 1997, the rate of startup formation has precipitously declined for firms operated by U.S. PhD recipients in science and engineering. These are supposedly the source of some of our best new technological and business opportunities. We link this to an increasing burden of knowledge by documenting a long-term earnings decline by founders, especially less experienced founders, greater work complexity in $\mathrm{R} \& \mathrm{D}$, and more administrative work. The results suggest that established firms are better positioned to cope with the increasing burden of knowledge, in particular through the design of knowledge hierarchies, explaining why new firm entry has declined for high-tech, high-opportunity startups.
\end{abstract}

\footnotetext{
* Åstebro is the L’Oréal Professor of Entrepreneurship at HEC Paris, Braguinsky is associate professor at the University of Maryland's Robert H. Smith School of Business, College Park, Maryland, a research associate at the NBER Productivity, Innovation and Entrepreneurship program and professor (cross-appointment) at Osaka University Institute of Social and Economic Research, and Ding is a PhD student at the University of Maryland's Robert H. Smith School of Business, College Park, Maryland. e-mail addresses are astebro@hec.fr, sbraguinsky@rhsmith.umd.edu, and yuheng.ding@rhsmith.umd.edu. Åstebro is the corresponding author. The use of NSF data does not imply NSF endorsement of the research methods or conclusions in the paper.
} 


\section{Introduction}

In the U.S. and across many countries, business dynamism is receding, as seen in declining firm entry rates and a falling employment share in new firms (e.g., Decker et al. 2014; Akcigit and Ates, 2019a). Is this something to worry about? Some emphatically say "yes": "A country cannot be great over a sustained period without a steady flow of great new firms" (Klepper, 2016, p. 62). However, the decline in the rate of startups and employment might not be anything to be very concerned about as long as it applies mainly to mom-and-pop stores and is explained by the increasing diffusion of efficient franchises, replacing individually run enterprises with expert managers of franchises of multiunit firms, as suggested by Lucas (1978) as the normal evolution of industries.

Alternatively, it might be of grave concern if the rate of entry and the share of employment by young firms are declining among high-opportunity firms from which most new technologies and business opportunities typically originate (Schumpeter, 1942). Although suggested that, for example, the supply of innovations is drying up (Gordon, 2016) or at least has become more difficult to achieve (Jones, 2009; Bloom et al., 2020), we still know little about the trend in business dynamics among high-tech, high-opportunity startups. ${ }^{1}$

We employ the nationally representative Survey of Doctorate Recipients to show a decline over the past 20 years in both the rate of startups founded and the share of employment at startups by the highest-educated science and engineering portion of the U.S. workforce. The declines are wide-ranging and not driven by any particular founder demographic category or geographic region or scientific discipline.

A potential source of this decline is the exponential increase in the amount of scientific knowledge. ${ }^{2}$ Medicine is a poignant example: "It is estimated that the doubling time

\footnotetext{
${ }^{1}$ For evidence of the importance of high-growth young firms, see Decker et al. (2016a, 2016b).

${ }^{2}$ We leave aside various other reasons for the general decline in business dynamics suggested in the literature (see e.g. Akcigit and Ates, 2019a; 2019b; Decker et al., 2016b) but we examine some potential alternative explanations for the decline specific to high-tech, high-opportunity startups in the robustness/extensions section.
} 
of medical knowledge in 1950 was 50 years; in 1980, 7 years; and in 2010, 3.5 years... What was learned in the first 3 years of medical school will be just $6 \%$ of what is known at the end of the decade from 2010 to 2020" (Densen, 2011). The impact of the so-called increasing burden of knowledge has previously been analyzed with respect to the organization of science (Jones, 2009). It has been argued to be a driving factor in the increase in teamwork for research and patenting (Wuchty et al., 2007), the increasing age at which $\mathrm{PhDs}$ are obtained, and an increased specialization of PhD work (Jones, 2009). The latter can be seen for example by the decrease in the number of physicians entering practice as general internists from 35\% during 1991-2000 to 12\% during 2011-2015 (Dalen et al., 2017).

We argue and find that an increasing burden of knowledge also leads to fewer hightech high-opportunity startups. We argue and find that it also leads PhDs to amass greater work experience before becoming a founder, to shoulder more R\&D tasks as founders, and not being rewarded for that extra work. Working for existing firms has, therefore, become considerably more attractive. Our argumentation links insights from three strands of literature: the increasing burden of knowledge, the organization of knowledge, and on the declining business dynamism, specifically at high-tech, high-opportunity firms.

The decline in startups is illustrated with the medical sector where 48.5 percent of physicians worked as independent practice owners in 2012, but where only 31.4 percent were independent owners in 2019 (Merritt Hawkins, 2019). Speaking of the shrinking gap in earnings, John A. Bergfeld of Cleveland Clinic added, "it used to be my colleagues in private practice made double to three times what I make. I do not think it is that way anymore."3

Exploring the impacts of the increasing burden of knowledge, we compare individuals with a $\mathrm{PhD}$ in science and engineering either as founders of incorporated startups

\footnotetext{
3 Press, Robert, 2011. "Private practice vs. salaried employment: A complicated decision.” Healio, January 01. https://www.healio.com/news/orthopedics/20120325/private-practice-vs-salaried-employment-a-complicateddecision.
} 
or as workers employed by established companies. We examine unique microdata on the evolution of work experience, earnings and wages, the change in the returns to experience, the change in the number of R\&D and other tasks performed, and the trends in the span of control (direct reports) and the depth of the hierarchy (indirect reports) for these two groups.

We find that the number of different $R \& D$ tasks has increased more for founders than for workers. And the returns to experience have increased over time for founders but not for workers, highlighting the increasing need for a single person — the founder — to cope with the burden of knowledge in startups. Workers at established firms have, instead, comfortably narrowed their span of control, employed more people indirectly under their control to support their work, and kept administrative duties low. They are also better rewarded for taking on more diverse work and managerial responsibilities than founders. All evidence suggests that established firms have coped more effectively with the increasing burden of knowledge in science by better utilizing the division of labor in innovative work through reorganizing tasks and hierarchies.

The literature on efficient knowledge hierarchies (Caliendo and Rossi-Hansberg, 2012; Garicano, 2000; Garicano and Rossi-Hansberg, 2004) can be used to explain how large organizations cope with the increasing burden of knowledge. As more innovation work exceptions are reported by lower-level workers, the firm responds by increasing the number of layers to handle the increasing volume of reports, and by narrowing the variance in reports to allow greater job specialization. Increasing the number of layers of management adds a fixed cost of operations, and narrowing task diversity may lower wages. Caliendo and RossiHansberg (2012) show that larger firms are more likely to become hierarchically taller by adding more layers of management when the number of managerially actionable exceptions passed up the hierarchy increases, as they can more easily absorb the added fixed cost. Founders at startups appear not to have recourse to this mitigation strategy. 
The rest of the paper is organized as follows. In Section 2 we briefly describe the data, with more exhaustive information provided in the Online Appendix. In Section 3 we document a declining startup rate and a declining employment share at startups for U.S. $\mathrm{PhD}$ recipients in science and engineering. In Section 4 we examine the impact of the increasing burden of knowledge as a possible explanation for the decline in startup rates and show that startup founders have been hit much harder by this burden than workers at established firms. Section 5 contains robustness checks and some extensions. Section 6 concludes.

\section{Brief data description}

The Survey of Doctorate Recipients (SDR) is a nationally representative survey of $\mathrm{PhD}$ recipients in science and engineering from U.S. PhD-granting institutions. We employ restricted-use data from all available surveys conducted (for most part) biannually between 1995 and 2017. We limit the sample to those who reside in the U.S. and report being employed full time with non-zero salaries, whose principal employer is either a private-sector for-profit company or organization, or who are self-employed or business owners at their own business at the time of the survey. Information about startups comes from answers to the question asking whether one's principal employer "c[a]me into being as a new business within the past five years." This question was not asked in the 1995, 2006, and 2008 surveys. Most of our analyses therefore start with the year 1997. We call businesses that did not come into being within the prior five years "established businesses."

Incorporated businesses have been found to be considerably more entrepreneurial and pursue better business opportunities than nonincorporated ones (Shane, 2009; Hurst and Pugsley, 2011; Åstebro and Tåg, 2017; Levine and Rubinstein, 2017). In this paper, we therefore focus on owners of incorporated startups, whom we call "founders." This term refers to owners at the time observed in the data, whose startups were their full-time primary 
employer and who drew non-zero salaries. We also sometimes use the term "startup rate" as a shortcut when referring to the share of founders among all incorporated business owners.

We further examine individuals' engagement in R\&D tasks. The SDR data contain responses to the question "Which of the following work activities occupied at least 10 percent of your time during a typical week on the job?" The list of possible alternatives includes 14 different activities. See Table A2 (all figures and tables starting with the letter A are in the appendix). We call these "tasks" and follow the classification suggested by the SDR to identify four of those activities as "R\&D" tasks: "basic research," "applied research," "development," and "design." We add up tasks in the R\&D category to obtain the number of R\&D tasks performed by founders and workers. We also follow the SDR-suggested classification to identify management and administration work activities (abbreviated as “management" tasks), which consist of five categories: "accounting, finance, contracts," "human resources," "managing or supervising people or projects," "sales, purchasing, marketing, customer service, public relations," and "quality or productivity management."

As in recent empirical work on knowledge-based hierarchies (e.g. Caliendo et al., 2015; Guadalupe and Wulf, 2010; Tåg, 2013; Tåg et al., 2016), we infer firms’ hierarchical structure based on microdata from workers' and founders' work tasks at their firms. Specifically, SDR provides data on the number of people supervised directly and indirectly by each respondent. Following Guadalupe and Wulf (2010), we call the former "span of control" and the latter "depth of the hierarchy."

\section{The startup founding rate and the dynamics of the employment share at startups}

Figure 1 displays the large decline over the past two decades in the share of founders among PhDs in science and engineering. In 1997, 34 percent reported being a founder of a startup, but by 2017 this rate had declined to 21 percent, a decline of 38 percent. This observation 
alone would not be sufficient to conclude that high-tech high-opportunity startups are on the decline because there could be fewer founding teams, but each could be getting larger. However, as also shown in Figure 1, the employment share of science and engineering $\mathrm{PhDs}$ at startups is also falling over time. ${ }^{4}$ The downward trend is not driven by any particular category of PhDs. For example, figures similar to Figure 1 for males versus females, whites versus non-whites, California versus the rest of the U.S., and for U.S. versus non-U.S. born $\mathrm{PhDs}$ differ in levels but their dynamics are almost exactly the same as those in Figure 1. See Figures A1-A6. The dramatically falling share of founders and employment at startups raises the prospect of a drying up of high-tech, high-opportunity startups.

--- Figure 1 around here ---

\section{Evidence of an increasing burden of knowledge}

What factors can explain the decline in high-tech, high-opportunity startups? We focus on the impact of an increasing burden of knowledge in science and engineering. If the increasing burden of knowledge is especially hard to handle at startups, we would expect to see a decline in the rate of startups. And if having more work experience is akin to prolonging the training in preparation for shouldering the burden of knowledge as a founder (cf. Jones, 2009), we would expect to see greater work experience among founders. We would also expect experienced founders to develop an earnings advantage over less experienced founders.

Consistent with the burden of knowledge increasing for founders, the years of work experience among founders shows a steady increase. The regression results imply that the average founder had about 14 percent longer post- $\mathrm{PhD}$ work experience in 2017 than in 1997. See Table A11. Further, Figure 2 illustrates a pronounced decline over time in the earnings of

\footnotetext{
${ }^{4}$ Uniquely, the employment share of PhDs at startups increased from about 11 percent in 1997-99 to more than 15 percent in 2001, possibly reflecting the dot-com boom (see Hombert and Matray, 2019).
} 
less experienced founders relative to their more experienced peers. Here, we separate less and more experienced founders by the median number of years after $\mathrm{PhD}$ (13 years), although other reasonable cut-offs lead to similar results. Between 1997 and 2001, founders with post$\mathrm{PhD}$ experience at or below the median earned more than the rest of the sample (consistent with Ouimet and Zarutskie, 2014), but by the 2010s, the situation is reversed, with less experienced founders earning on average 30-40 percent less than other founders. Prior work experience apparently is becoming much more valuable for founders over time. The earnings of less experienced founders declined not just in relative but also in absolute terms. The average inflation-adjusted earnings of founders with below the median post- $\mathrm{PhD}$ experience were $\$ 72,616$ in 1997 , whereas 20 years later their earnings were $\$ 57,517$, a decline of more than 20 percent (Table A3 presents full survey data).

--- Figure 2 around here ---

Running a startup might constrain founders' ability to organize its hierarchy efficiently, at least until it has succeeded in growing well beyond its initial size. As science accumulates more knowledge, we would therefore expect $\mathrm{PhD}$ founders to have to take on more R\&D tasks. The SDR sample offers a unique opportunity for pursuing this line of inquiry using detailed, individual-level data on founder and worker tasks. We also explore how startups and established firms differ in their organization of work, guided by the theory of knowledge hierarchies (e.g., Garicano, 2000).

\subsection{The number of $R \& D$ tasks is rising, but established firms take advantage of a division of labor and knowledge hierarchies}

Figure 3, Panel A, illustrates the dynamics of the total number of tasks reported by founders and, separately, the number of R\&D and management tasks. The total number of tasks (with a theoretical maximum of 14) is measured on the left-hand scale whereas the number of 
management and R\&D tasks, whose maximum is five and four, respectively, are measured on the right-hand scale. The average number of all tasks for founders increased by about 15 percent from the beginning to the end of our sample, a statistically significant difference using a double-sided $t$-test. Furthermore, although the number of both R\&D and management tasks increased, the increase is more pronounced in $\mathrm{R} \& \mathrm{D}$, for which it rose by more than 50 percent from 1997 to 2017 . Importantly, the increase in R\&D tasks was equally pronounced at all experience levels (column (1) in Table 1 below). As a result, R\&D tasks that comprised about 25 percent of all tasks conducted by founders in 1997 increased to 34 percent of all tasks in 2017. As can be seen in Figure 3, this was not accompanied by any decline in management tasks, so the founders had to shoulder the burden of doing more R\&D tasks while also running the same or more administrative tasks.

--- Figure 3 around here ---

Panel B of Figure 3 presents the trends for workers at established firms. Workers were also affected by the need to perform more R\&D tasks, as the increase in the number of $R \& D$ tasks from 1997 to 2017 is about 12 percent. Notably, however, as the figure reveals, workers did not need to handle more management tasks, which remained relatively flat for them. Also, founders had to deal with significantly more management tasks than workers in terms of levels: about 30-40 percent more at the beginning of the study period, increasing to 50 percent more at the end. The explanation for this difference likely lies in how the two types of firms differ in their organization of work, which we analyze below. ${ }^{5}$

Based on these initial observations, we conjecture that established firms were able to take better advantage of a division of labor in innovation and organize knowledge hierarchies more efficiently. To examine this further while accounting for various other differences

\footnotetext{
${ }^{5}$ Another potential explanation is that the breadth of tasks is better rewarded for founders than workers, as in Lazear (2005). However, note that whereas founders take on more tasks, they are not rewarded for doing so.
} 
between founders and workers, we turn to regression analysis. The estimation equation, estimated separately on the samples of founders and workers at established firms, is

$$
y_{i t}=\alpha+\beta_{1} t+\beta_{2} \exp _{i t}+\boldsymbol{\gamma} \cdot \boldsymbol{X}_{i t}+\varepsilon_{i t},
$$

where $y_{i t}$ denotes outcome variables for individual $i$ at time $t$, which are (a) the number of R\&D tasks, (b) the span of control, and (c) the depth of the hierarchy; $t$ is the time trend; $\exp _{i t}$ denotes experience (years after $\mathrm{PhD}$ is received) of individual $i$ at time $t ; \boldsymbol{X}_{i t}$ is a vector of controls, consisting of demographic, occupational, and geographic location dummies; and $\varepsilon_{i t}$ is the error term. Estimation results are presented in Table $1 .^{6}$

--- Table 1 around here ---

First, coefficients on the time trend variable in columns (1) and (2) in Panel A confirm a positive time trend in the number of $R \& D$ tasks for both founders and workers at established firms, with a somewhat stronger trend for founders. Second, coefficients on work experience show that workers at established firms, but not founders, tend to perform fewer R\&D tasks as their experience grows. This suggests that established firms employ a greater division of labor in innovation by assigning less experienced workers to R\&D tasks and more experienced workers to team leadership roles. In Panel B we dig deeper into this by looking at the span of control and the depth of the hierarchy. Neither the span of control nor the depth of hierarchy changes over time for founders. Although more experience is associated with somewhat deeper hierarchies for founders, the coefficient is relatively small and statistically only marginally significant. Needless to say, most startups are small, so opportunities to restructure startups to counter the increasing burden of knowledge must be inherently limited.

In contrast, both the span of control and the depth of the hierarchy (especially the latter) strongly increase with experience for workers at established firms, in line with such

\footnotetext{
${ }^{6}$ To ease interpretation and to conform with the specification of earnings regressions in the next section, we report the results of estimations for log-transformed dependent variables using the inverse hyperbolic sine (IHS) transformation. The results are qualitatively similar to those with non-log-transformed values.
} 
workers performing fewer R\&D tasks as they age, as shown in column (2) in Panel A.

Strikingly, the coefficient on the time trend for the span of control in column (4) is negative, indicating that the span of control decreases for workers at established firms on average by about 0.46 percent per year (statistically highly significant). However, the coefficient on the time trend for the depth of the hierarchy in column (6) is positive, also statistically highly significant, indicating that hierarchies deepen over time for workers at established firms on average by about 0.32 percent per year. Together, the results suggest that established firms cope with the increasing burden of knowledge on their workers by introducing additional layers of hierarchy, while simultaneously reducing the number of employees who report directly to managers, as suggested in the literature on efficient knowledge hierarchies. ${ }^{7}$

We probed the data further by looking at the sample limited to workers at firms with 5,000 or more employees. These firms account for about half the workers at established firms in our sample. If, as we conjecture, the increasing burden of knowledge can be mitigated by introducing costly additional layers of management, large firms should have greater opportunities to implement these organizational changes. This should lead to a higher number of indirectly supervised individuals. Hence, we re-estimated equation (1) for workers at large firms. The results, reported in Table A4, show that hierarchies deepen over time at twice the rate for workers at large firms as for workers at all firms. In addition, for workers at large firms, the number of R\&D tasks increases by about half the increase for founders and also significantly more slowly than for all workers. Thus, other things equal, large firms mitigate the impact of the increase in the burden of knowledge better than small firms, and this appears to be related to hierarchies that grow taller more quickly at large than at small firms.

\footnotetext{
${ }^{7}$ Suppose that a firm initially consisting of two R\&D teams with 10 members each added a second layer made up of a single manager, promoted from a supervisory position on one of the teams. The newly promoted manager had nine direct reports before the change but now has zero direct and 19 indirect reports. Her replacement within her former team will now have eight, not nine, direct reports. More generally, reorganizing a firm by adding layers of hierarchy while holding the firm size constant can be seen as accompanied by a decrease in the number of direct reports and an increase in the number of indirect reports.
} 


\subsection{Earnings dynamics of founders versus workers at established firms}

As mentioned in Section 3, founders did not appear to receive higher earnings over time, despite having to cope with an increasing number of R\&D and management tasks. In Table 2 we examine this with an earnings regression. The estimation equation is similar to Equation (1) except that the outcome variable is now the (logged) salary of individual $i$ at time $t$, while the explanatory variables of interest include the (IHS-transformed) number of R\&D tasks, the span of control, and the depth of the hierarchy, and there is an interaction term between the time trend and experience. We present results in Table 2 separately for founders and workers at established firms. This avoids well-known specification problems associated with how wages and entrepreneurial earnings are reported. Several things stand out.

Founders' earnings decline on average by about 1.6 percent per year (column 1). However, this is offset by an opposite time trend in returns to experience. The mean number of years after founders receive a $\mathrm{PhD}$ is 15.9 years; hence, the coefficient on the interaction term between experience and time implies that, at the mean work experience, the negative baseline time trend is completely offset.

In stark contrast to founders, workers' real earnings grow over time, although the increase is relatively small, 0.4 percent per year (column 2). Earnings for workers at established firms are concave in experience. The trend toward increasing returns to experience is much weaker among workers than among founders; at the mean number of years after receiving a $\mathrm{PhD}$ (12.5 years), earnings grow extra by just 0.125 percent per year.

--- Table 2 around here ---

Performing more R\&D tasks is associated with significantly higher earnings for workers at established firms. Doubling the number of R\&D tasks increases their earnings by 4.4 percent. The point estimate for founders is similar in magnitude, but the standard errors are high so the most we can say in this case is that, controlling for all other factors (including 
the time trend, experience, the interaction of the two, etc.), more R\&D tasks are tentatively associated with higher earnings, but there is large variance in outcomes.

Finally, both a larger span of control and hierarchical depth seem to be associated with higher earnings for both founders and workers. Recall that Table 1 showed no increase in the span of control or hierarchical depth for founders over time. Nevertheless, a larger span of control or hierarchical depth provides economic compensation. Hence, the lack of change in these features for founders is likely explained by their inability to offset the increasing burden of knowledge by more efficiently organizing tasks at their startups.

\section{Robustness and alternative explanations}

We wanted to gain insights about the dynamics of Schumpeterian startups, which are the most likely to contribute to innovation and growth in the economy. For that purpose, we studied founders with a $\mathrm{PhD}$ in science and engineering and their incorporated startups. In this section, we briefly examine what happens if we perturb that measure and also consider some potential alternative interpretations of our findings.

\subsection{Type of entrepreneurial opportunity}

Following a series of articles showing that incorporated businesses pursue the highest opportunities, we analyze only founders of incorporated startups. However, also including founders of unincorporated startups in the analysis yields similar findings, provided the sample is limited to founders whose job and education are closely related (see Braguinsky et al., 2012; Ohyama, 2015). The details are in Appendix E.

\section{2. $R \& D$-focused individuals}


In addition to the list of the work activities on which individuals spent at least 10 percent of their time on the job, SDR asks the question "On which work activity did you spend most of your time during a typical week on the job?" We call founders who listed $R \& D$ as their primary work activity "R\&D-focused" founders. We examine these founders (and workers) to see whether the results are, potentially, even more extreme for these founders.

Note that an R\&D-focused founder and a startup engaged in R\&D might not be the same thing. A startup might be primarily engaged in R\&D whereas the founder primarily manages a team of researchers. An increasing burden of scientific and technological knowledge, leading to an increasing number of exceptions brought to the attention of the founder, might change this, however, shifting the primary work activity of the founder from management to R\&D. In fact, that interpretation appears to be most consistent with the data.

The first thing to note is that R\&D-focused founders as a share of all founders increases over time - from 26.1 percent in 1997 to 31.6 percent in 2017, an increase of 21 percent (see Table A7). However, the share of R\&D-focused business owners among all business owners irrespective of firm age rises even faster, from about 12 percent in 1997 to over 30 percent in 2017, suggesting that the burden of knowledge is widespread. As a result, the rate of R\&D-focused startups steeply declines, and this decline, from 54 percent in 1997 to 20 percent in 2017, is larger in magnitude than the decline in the overall startup rate shown in Figure 1. Notably, the share of R\&D-focused workers at established firms remains basically flat over time, fluctuating at around 50 percent.

The increasing burden of knowledge is also reflected in a steeper earnings decline for R\&D-focused founders. In Table A8, we present the estimation results from the same regression for which results were in Table 2, but with the sample limited to R\&D-focused founders. The negative earnings time trend is much more pronounced for R\&D-focused 
founders than for all founders-the decline at the baseline is more than 4.4 percent per year and statistically highly significant. Table A9 present changes in levels.

In summary, we find that R\&D-focused owners are becoming more plentiful among both startup founders and other business owners, the startup rate is declining more rapidly for R\&D-focused founders than for all founders, and earnings are declining more rapidly for R\&D-focused founders than for all founders.

\subsection{Limited scope for the burden of knowledge?}

Could it be that the burden of knowledge is limited to certain fields of science? For example, since the bioengineering revolution created by the invention of rDNA in 1973 by Herber W. Boyer and Stanley N. Cohen, the life sciences have raced forward, but mechanical engineering has not. However, we have already provided evidence that the decline in business dynamics is not driven by any particular category of $\mathrm{PhDs}$. Further, our regression specifications (Tables 1 and 2) include detailed occupational dummies, controlling for differences between bioengineers and mechanical engineers in their work.

In Appendix $\mathrm{H}$, we use information about $\mathrm{PhD}$ specializations and redo our main analyses. Specifically, we sort PhDs into two groups: those where science has built up rapidly over the past forty years, and those that have not experienced such a rapid increase. Then, the levels do indeed appear different. $\mathrm{PhD}$ founders who are more science based perform more R\&D tasks. However, the general time trends already reported are found to apply universally, albeit with one major difference. The drop in the share of founders is more pronounced for $\mathrm{PhDs}$ that are more science based. This result provides further support for the conclusion that the increasing burden of knowledge is driving the decline in business dynamics among hightech, high-opportunity startups. 


\subsection{Declining human capital?}

A decline in the human capital of founders might explain the decline in high-tech, high-opportunity startups and their founders' earnings. For example, using data in the U.S. manufacturing sector, Ayyagari and Maksimovic (2017) find a declining trend in skill levels, especially in cognitive skills among new entrants. We employ a standard approach (see Choi et al., 2019; Azoulay et al., 2020) with prior salaries as a measure of the human capital of future founders. The results, presented in Figure A8, show that although the predicted prior salaries of future founders tended to be lower than of those who stay in paid work in the 1990s, the ordering was reversed in the 2008 and 2010 surveys while the two were at about the same level in the 2015 survey. Furthermore, we examined the share of founders who graduated from top-ranked $\mathrm{PhD}$ programs. Consistent with the findings about pre-transition salaries, around 5 percent more founders graduated from top-ranked programs in the 2010s than in the late 1990s and early 2000s (Figure A10). Hence, both prior salaries and the quality of education received by founders have increased over time. In short, we find no evidence that the declining trend in the startup rate and in earnings of founders could be due to a fall in the ability or education quality of founders over time. ${ }^{8}$

\subsection{Declining supply of PhDs?}

Could the decline in the creation of high-tech, high-opportunity startups somehow be driven by a decline in the number of PhDs? It appears not. The overall supply of recent science and engineering $\mathrm{PhD}$ recipients has demonstrated a strong upward trend since 1997 (see Figure A13). The number of $\mathrm{PhDs}$ awarded in science and engineering fields increased from 28,486 in 1997 to 41,294 in 2017 (National Science Foundation, 2019).

\footnotetext{
${ }^{8}$ Increasing human capital of founders is consistent with a "selection effect" due to higher barriers to entry that, according to our story, stem from the increasing burden of knowledge. Note that this does not have to lead to an increase in average earnings of the remaining founders, because the increasing burden of knowledge reduces earnings at all levels of human capital.
} 


\subsection{Increasing Age of Founders?}

Over the past few decades, the U.S. population has been aging. Since young people tend to disproportionately found or join new businesses (Ouimet and Zarutskie, 2014), the aging of those receiving PhDs could explain the decline in Figure 1 (Hopenhayn et al., 2018; Karahan et al., 2019). However, if we define "young" as those below the median age of 45 (or any other reasonable cutoff, for that matter), the share of such young founders in the total number of all founders was stable, about 35-40 percent throughout the period studied. In Figure A7, we also show that the age at which individuals receive their $\mathrm{PhDs}$ in science and engineering had increased steadily until about 1993 - the average recipient was 28.7 years old in 1971 and 31.3 years old in 1995. Then, the average age of $\mathrm{PhD}$ recipients stopped increasing and even declined after 2003 - the average recipient in 2015 was 30.3 years old. Apparently, the age of founders is not strongly associated with the decline in high-tech, highopportunity startups. ${ }^{9}$

\subsection{Dot Com Bubble Effects?}

Since the starting period of our data coincides with the advent of the dot com boom, the decline could just be an anomaly. We therefore reconstructed Figure 1 excluding computer-related occupations (Figure A14) and excluding individuals who performed computer-related tasks (Figure A15). The trends without computer-related occupations are the same as in Figure 1, suggesting a widespread decline that is not specific to computing. Also, Table A12 shows that the overall share of $\mathrm{PhDs}$ in computer-related occupations is stable among incorporated business owners while it slightly increases over time among those

\footnotetext{
${ }^{9}$ In contrast, as mentioned above, accumulated work experience (years after $\mathrm{PhD}$ ) prior to founding a startup did tend to increase over time. Startup founders appear to have been receiving their doctorate degrees at a younger age over time. See Appendix H, Table A11 and the discussion there.
} 
employed in industry. None of these two latter trends shows a clear relationship to the declining trend in startups, suggesting that the dot com boom and bust is not the culprit.

\subsection{Declining Venture Capital?}

A simple explanation for the decline in high-tech, high-opportunity startups is that the aggregate amount of venture capital for startups has declined. However, the supply of venture funding has substantially increased since the dot com crash. For example, the amount of global venture capital investments increased tenfold, from \$25 billion in 2004 to $\$ 254$ billion in 2018 (National Venture Capital Association, 2019). More than 8,380 venture-backed companies received $\$ 131$ billion in funding in 2018, surpassing the $\$ 100$ billion mark set at the height of the dot-com boom in 2000. For more detail on how venture capital has shifted over the years, see Lerner and Nanda (2020).

\section{Discussion}

We have established a couple of new facts regarding business dynamism among high-tech, high-opportunity startups run by $\mathrm{PhDs}$ in science and engineering. Since 1997, the share of founders in these startups has declined by around 38 percent, not limited to any particular founder demographic or ethnic group or occupation, and this decline is widespread across regions of the United States. The share of workers at startups has followed the same path of decline.

There is a significant trend toward an increasing amount of work experience among founders (although not their age), pointing to the burden of knowledge as an explanation for the decline in startup rates. Probing this idea in the data, we show evidence that founders are rewarded for building experience, as they have had to perform an increasing number of R\&D tasks over time while also increasing the number of other tasks that they have to perform. 
Nevertheless, founders' earnings generally do not reflect that added workload, as average earnings have been declining, especially for less experienced founders.

The data further suggest that established firms have an advantage over startups in creating a division of labor in $\mathrm{R} \& \mathrm{D}$, in particular by introducing more hierarchical layers, reducing knowledge workers' span of control, and allocating more experienced workers to positions with greater managerial responsibility. Further, established firms compensate workers for performing more R\&D tasks and supervising more individuals. These developments are not seen among founders. The differences follow from the natural limits imposed by running a small firm with less division of labor and a high amount of multitasking by the founder. The largest firms are even more active in reorganizing job tasks, increasing the depth of hierarchy at twice the rate of all established firms.

Why don't founders hire more specialized workers and start with bigger teams and build a richer hierarchy, as established firms do? Although we do not address this follow-on question, we can at least speculate. Some of the answers might be that startups face high uncertainty about the viability of their businesses and thus start small, and either grow or exit as uncertainty diminishes; and/or most startups are financially constrained and cannot afford to hire larger teams. We leave it to future research to explore these ideas.

As noted in the introduction, a steady flow of great new high-tech firms is generally agreed to be necessary for an economy to remain vibrant in the long run. In this sense, our findings present cause for concern. It is not immediately clear what the remedy is. Typical regulatory actions, such as changing taxation rates or restricting or enlarging businesses' operating conditions would likely have no effect. And restricting established firms' ability to make organizational design changes seems highly unlikely to pass any legislature. Our findings suggest that if the goal is to restore business dynamism in the high-tech sector, alleviating the burden of knowledge should be front and center in the strategy to attain it. 


\section{References}

Akcigit, Ufuk, and Sina T. Ates. 2019a. "Ten Facts on Declining Business Dynamism and Lessons from Endogenous Growth Theory.” NBER Working Paper 25755.

Akcigit, Ufuk, and Sina T. Ates. 2019b. "What Happened to U.S. Business Dynamism?" NBER Working Paper 25756.

Åstebro, Thomas, and Joacim Tåg. 2017. "Gross, Net, and New Job Creation by Entrepreneurs.” Journal of Business Venturing Insights 8 (November): 64-70.

Ayyagari, Meghana, and Vojislav Maksimovic. 2017. "Fewer and Less Skilled? Human Capital, Competition, and Entrepreneurial Success in Manufacturing." https://ssrn.com/abstract=3093443. Accessed June 16, 2020.

Azoulay, Pierre, Benjamin F. Jones, J. Daniel Kim, and Javier Miranda. 2020. "Age and High-Growth Entrepreneurship.” American Economic Review: Insights 2 (1): 65-82.

Bloom, Nicholas, Charles I. Jones, John Van Reenen, and Michael Webb. 2020. "Are Ideas Getting Harder to Find?" American Economic Review 110 (4): 1104-1144.

Braguinsky, Serguey, Steven Klepper, and Atsushi Ohyama. 2012. "High-Tech Entrepreneurship." Journal of Law and Economics 55 (4): 869-900.

Caliendo, Lorenzo, Giordano Mion, Luca David Opromolla, and Esteban RossiHansberg. 2015. "Productivity and Organization in Portuguese Firms." NBER Working Paper 21811.

Caliendo, Lorenzo, and Esteban Rossi-Hansberg. 2012. "The Impact of Trade on Organization and Productivity." Quarterly Journal of Economics 127 (3): 1393-1467.

Choi, Joonkyu, Nathan Goldschlag, John Haltiwanger, and J. Daniel Kim. 2019.

"Founding Teams and Startup Performance." https://ssrn.com/abstract=3481850. Accessed June 16, 2020.

Dalen, James E., Kenneth J. Ryan, Joseph S. Alpert. 2017. "Where Have the Generalists Gone? They Became Specialists, Then Subspecialists." The American Journal of Medicine 130 (7): 766-768.

Decker, Ryan A., John Haltiwanger, Ron S. Jarmin, and Javier Miranda. 2016a. "Declining Business Dynamism: What We Know and the Way Forward." American Economic Review 106 (5): 203-207.

Decker, Ryan A., John Haltiwanger, Ron S. Jarmin, and Javier Miranda. 2016 b. "Where Has All the Skewness Gone? The Decline in High-Growth (Young) Firms in the U.S." European Economic Review 86 (July): 4-23.

Decker, Ryan, John Haltiwanger, Ron Jarmin, and Javier Miranda. 2014. "The Role of Entrepreneurship in US Job Creation and Economic Dynamism." Journal of Economic Perspectives 28 (3): 3-24.

Densen, Peter. 2011. "Challenges and Opportunities Facing Medical Education." Transactions of the American Clinical and Climatological Association 122: 45-58.

Garicano, Luis. 2000. "Hierarchies and the Organization of Knowledge in Production." Journal of Political Economy 108 (5): 874-904.

Garicano, Luis, and Esteban Rossi-Hansberg. 2004. "Inequality and the Organization of Knowledge." American Economic Review 94 (2): 197-202.

Gordon, Robert J. 2016. The Rise and Fall of American Growth. Princeton: Princeton University Press. 
Guadalupe, Maria, and Julie Wulf. 2010. "The Flattening Firm and Product Market Competition: The Effect of Trade Liberalization on Corporate Hierarchies." American Economic Journal: Applied Economics 2 (4): 105-127.

Hombert, Johan, and Adrien Matray. 2019. “Technology Boom, Labor Reallocation, and Human Capital Depreciation.” https://ssrn.com/abstract=3496625. Accessed June 16, 2020.

Hopenhayn, Hugo, Julian Neira, and Rish Singhania. 2018. "From Population Growth to Firm Demographics: Implications for Concentration, Entrepreneurship and the Labor Share.” NBER Working Paper 25382.

Hurst, Erik, and Benjamin Wild Pugsley. 2011. "What Do Small Businesses Do." Brookings Papers on Economic Activity, 73-118.

Jones, Benjamin F. 2009. "The Burden of Knowledge and the 'Death of the Renaissance Man': Is Innovation Getting Harder?” Review of Economic Studies 76 (1): 283-317.

Karahan, Fatih, Benjamin Pugsley, and Ayşegül Şahin. 2019. "Demographic Origins of the Startup Deficit.” NBER Working Paper 25874.

Klepper, Steven. 2016. Experimental Capitalism: The Nanoeconomics of American HighTech Industries. Princeton: Princeton University Press.

Lazear, Edward. 2005. “Entrepreneurship.” Journal of Labor Economics 23(4): 649-680.

Lerner, Josh, and Ramana Nanda. 2020. "Venture Capital's Role in Financing Innovation: What We Know and How Much We Still Need to Learn.” NBER Working Paper 27492.

Levine, Ross, and Yona Rubinstein. 2017. "Smart and Illicit: Who Becomes an Entrepreneur and Do They Earn More?” Quarterly Journal of Economics 132 (2): 963-1018.

Lucas, Robert E. 1978. "On the Size Distribution of Business Firms.” Bell Journal of Economics 9 (2): 508-523.

Merritt Hawkins. 2019. 2019 Physician Inpatient/Outpatient Revenue Survey. Dallas, Texas: Merritt Hawkins.

National Science Foundation, National Center for Science and Engineering Statistics. 2019. Doctorate Recipients from U.S. Universities: 2018. Special Report NSF 20-301. Alexandria, VA. Available at https://ncses.nsf.gov/pubs/nsf20301/.

National Venture Capital Association. 2019. 2019 Yearbook. Washington, DC: National Venture Capital Association.

Ohyama, Atsushi. 2015. "Entrepreneurship and Job-Relatedness of Human Capital." Economica 82 (328): 740-768.

Ouimet, Paige, and Rebecca Zarutskie. 2014. "Who Works for Startups? The Relation between Firm Age, Employee Age, and Growth.” Journal of Financial Economics 112 (3): 386-407.

Schumpeter, Joseph A. 1942. Capitalism, Socialism and Democracy. New York: Harper \& Brothers.

Shane, Scott. 2009. "Why Encouraging More People to Become Entrepreneurs Is Bad Public Policy." Small Business Economics 33 (2): 141-149.

Tåg, Joacim. 2013. "Production Hierarchies in Sweden.” Economics Letters 121 (2): 210213. 
Tåg, Joacim, Thomas Åstebro, and Peter Thompson. 2016. "Hierarchies and Entrepreneurship." European Economic Review 89 (October): 129-147.

Wuchty, Stefan, Benjamin F. Jones, and Brian Uzzi. 2007. "The Increasing Dominance of Teams in Production of Knowledge.” Science 316 (5827): 1036-1039. 


\section{Figures and Tables}

Figure 1. Dynamics of the share of PhDs who are employed at or founders of startups

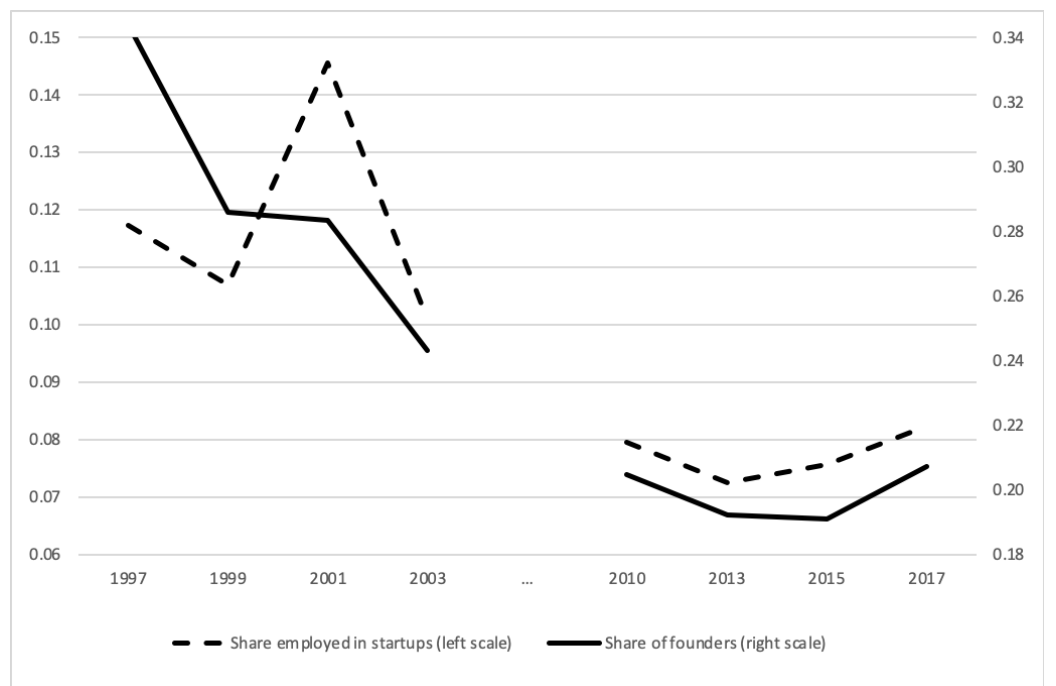

Notes: The figure reports the share of PhDs in science and engineering who are employed full-time with non-zero salaries in new (five years old or less) private for-profit companies (startups) compared with $\mathrm{PhDs}$ in science and engineering who are employed full-time with non-zero salaries in all private for-profit businesses. "Employed full-time" means working at least 48 weeks per year and at least 30 hours per week. The figure also reports the share of PhDs in science and engineering who are founders of startups in the total number of PhDs in science and engineering who are self-employed or owners of established businesses full-time with non-zero salaries. "Founders" are owners of/self-employed at an incorporated startup at the time observed in the data. The question of whether the business was a startup was not asked in the 1995, 2006, and 2008 surveys, so the data for those surveys are missing.

Figure 2. Dynamics of relative earnings of founders with below the median years after $\mathrm{PhD}$

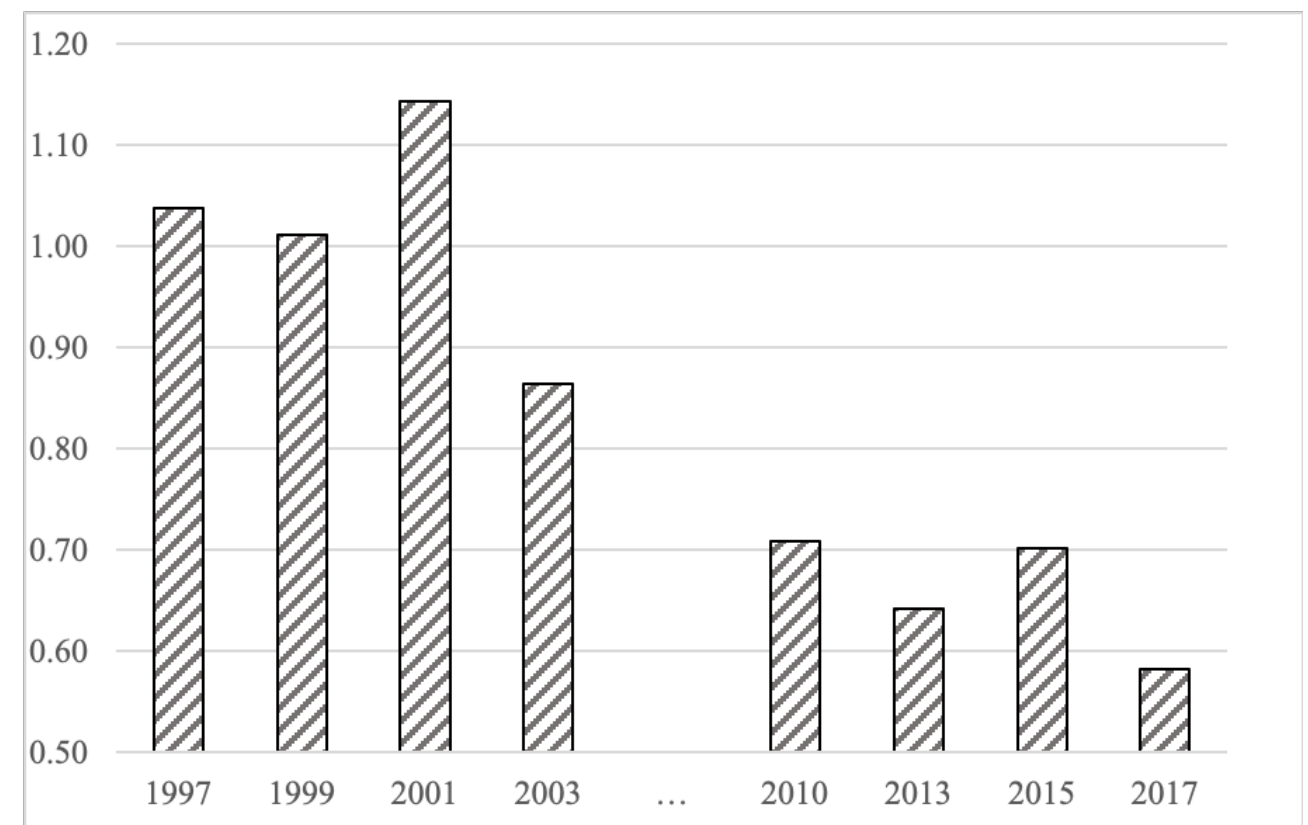

Notes: The figure reports the ratio of earnings of full-time incorporated startup founders with non-zero salaries and years after $\mathrm{PhD}$ at or below the median of 13 years, to earnings of full-time incorporated startup founders with non-zero salaries and 14 or more years after $\mathrm{PhD}$ among $\mathrm{PhDs}$ in science and engineering. The question of whether the business was a startup was not asked in the 1995, 2006, and 2008 surveys, so the data for those surveys are missing. 
Figure 3

Panel A. The number of all, R\&D, and management work activities among founders

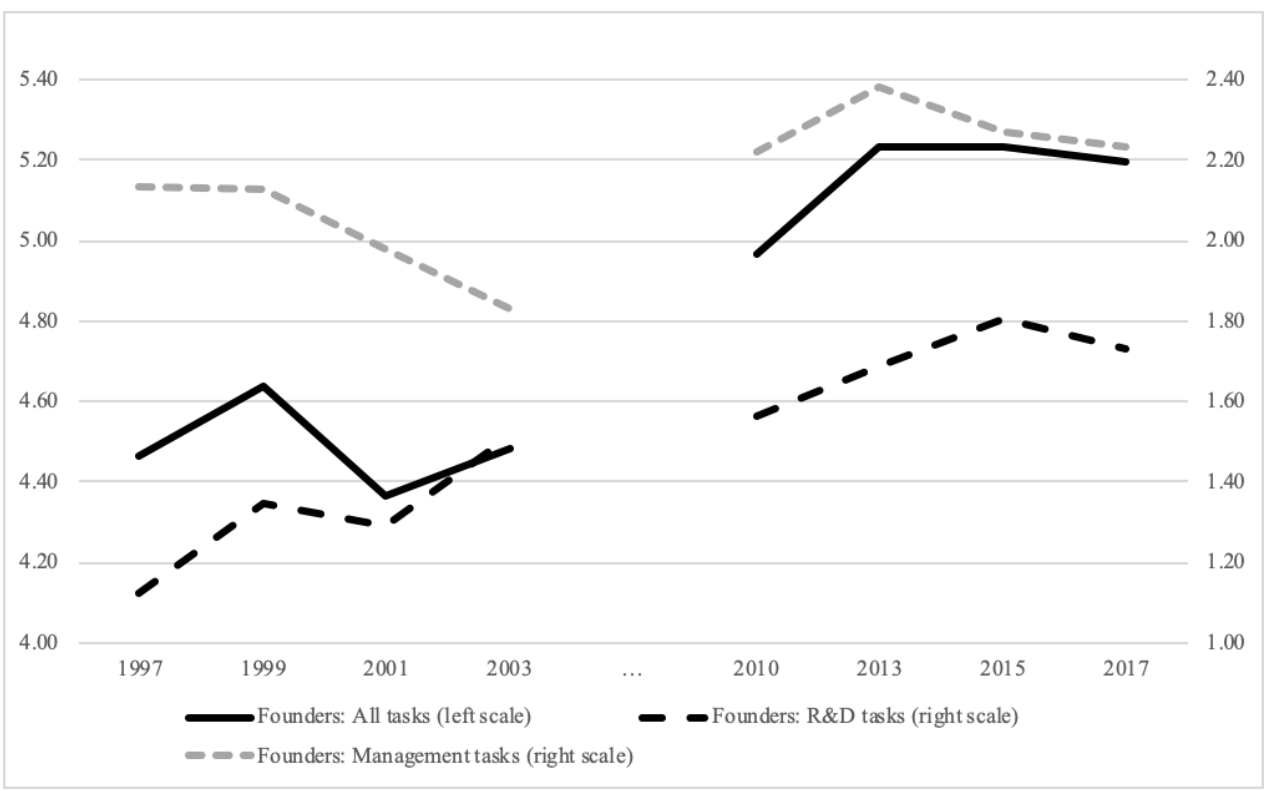

Panel B.

The number of all, R\&D, and management work activities among workers at established firms

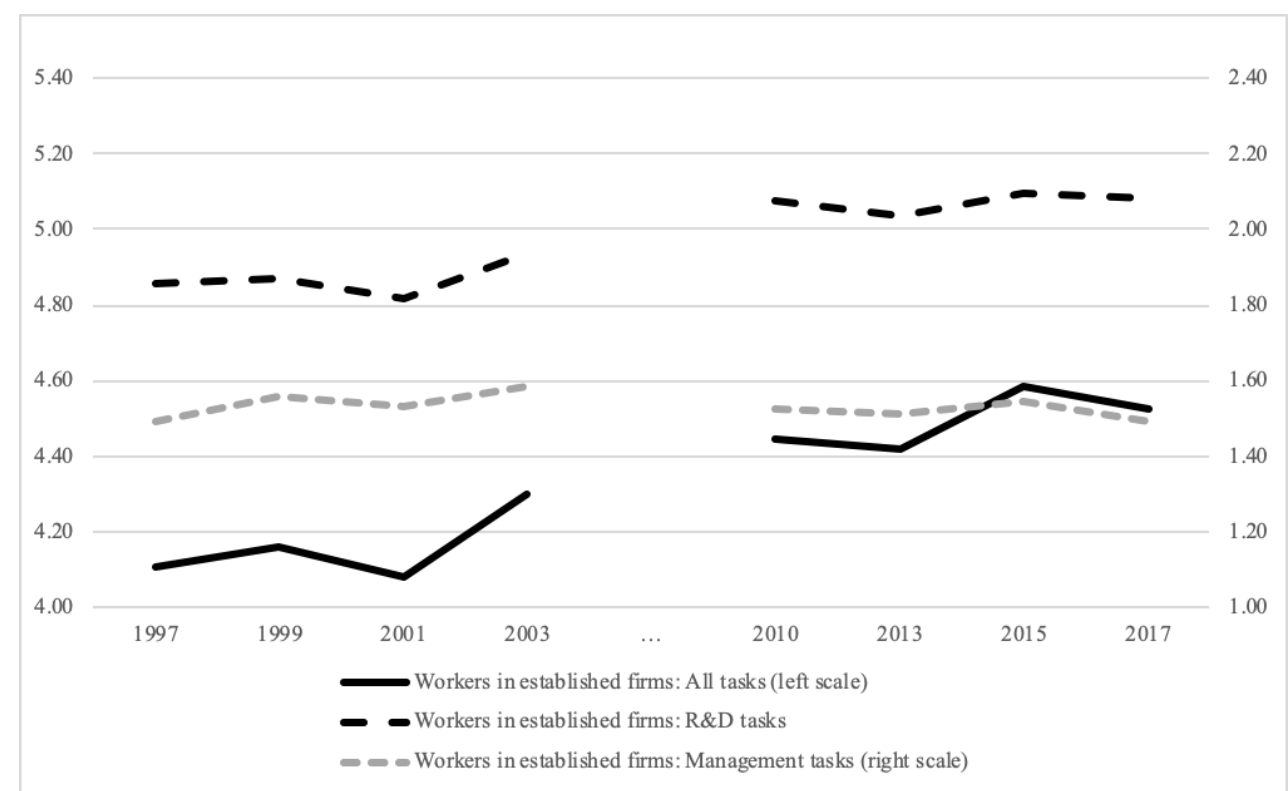

Notes: The sample consists of full-time founders of incorporated startups with non-zero salaries among PhDs in science and engineering. A startup is a firm that is five years old or less. Work activities that occupied at least 10 percent of their time during a typical workweek on their jobs. R\&D tasks consist of "basic research," "applied research," "development," and "design." Management (management and administration) tasks consist of "accounting, finance, contracts," "human resources," "managing or supervising people or projects," "sales, purchasing, marketing, customer service, public relations," and "quality or productivity management." The total number of work activities includes, in addition to the above, computer programming, employee relations, production, operations and maintenance, teaching as well as other work activities. See also Online Appendix Table A2. 
Table 1.

Panel A. Factors that affect the number of R\&D tasks.

\begin{tabular}{|l|c|c|}
\hline & \multicolumn{2}{|c|}{ DV: IHS-transformed number of R\&D tasks } \\
\hline & Founders (1) & Workers at established firms (2) \\
\hline \multirow{2}{*}{ Time } & $0.0109^{* * *}$ & $0.0075^{* * *}$ \\
& $(0.002)$ & $(0.000)$ \\
\hline \multirow{2}{*}{ Experience (years after PhD) } & -0.0021 & $-0.0052^{* * *}$ \\
& $(0.002)$ & $0.000)$ \\
\hline \multirow{2}{*}{ Constant } & $0.905^{* * *}$ & $0.953^{* * *}$ \\
& $(0.196)$ & $(0.048)$ \\
\hline Other controls: gender, ethnicity, & Included & Included \\
occupation, U.S. state of employment & 2,101 & 65,485 \\
\hline Observations & 0.345 & 0.274 \\
\hline R-squared & & \\
\hline
\end{tabular}

Panel B. Factors that affect the span of control and depth of the hierarchy

\begin{tabular}{|l|c|c|c|c|}
\hline & \multicolumn{2}{|c|}{$\begin{array}{c}\text { DV: span of control (IHS- } \\
\text { transformed \# of individuals } \\
\text { directly supervised) }\end{array}$} & \multicolumn{2}{c|}{$\begin{array}{c}\text { DV: depth of hierarchy (IHS- } \\
\text { transformed \# of individuals } \\
\text { indirectly supervised) }\end{array}$} \\
\hline & Founders (3) & $\begin{array}{c}\text { Workers at } \\
\text { established firms } \\
(4)\end{array}$ & Founders (5) & $\begin{array}{c}\text { Workers at } \\
\text { established firms } \\
(6)\end{array}$ \\
\hline Time & 0.0001 & $-0.0046^{* * *}$ & -0.0027 & $0.0032^{* * *}$ \\
& $(0.004)$ & $(0.001)$ & $(0.004)$ & $(0.001)$ \\
\hline Experience (years after PhD) & -0.0010 & $0.0064^{* * *}$ & $0.0051^{*}$ & $0.0101^{* * *}$ \\
& $(0.002)$ & $(0.001)$ & $(0.003)$ & $(0.001)$ \\
\hline Constant & $1.058^{* * *}$ & $0.686^{* * *}$ & $0.717^{*}$ & -0.054 \\
& $(0.405)$ & $(0.081)$ & $(0.413)$ & $(0.099)$ \\
\hline Other controls: gender, ethnicity, & Included & Included & Included & Included \\
\hline occupation, U.S. state of employment & 2,101 & 65,485 & 2,101 & 65,485 \\
\hline Observations & 0.208 & 0.218 & 0.264 & 0.470 \\
\hline R-squared & &
\end{tabular}

Estimation method: OLS. ${ }^{* *},{ }^{* *}$, and ${ }^{*}$ denote statistical significance at the 1 percent, 5 percent, and 10 percent levels, respectively. Because there are observations with a zero number of R\&D-related work activities as well as a zero span of control and depth of hierarchy, we use inverse hyperbolic sine (IHS) transformations, defined as $y=\ln \left(x+\sqrt{x^{2}+1}\right)$. 
Table 2. Earnings of founders and workers at established firms

\begin{tabular}{|c|c|c|}
\hline \multicolumn{3}{|l|}{ DV: Log(real earnings) } \\
\hline & $\begin{array}{l}\text { Founders } \\
\text { (1) }\end{array}$ & $\begin{array}{c}\text { Workers at } \\
\text { established firms } \\
\text { (2) }\end{array}$ \\
\hline Time & $\begin{array}{c}-0.0163 * * * \\
(0.006)\end{array}$ & $\begin{array}{c}0.0039 * * * \\
(0.001)\end{array}$ \\
\hline Experience (years after $\mathrm{PhD}$ ) & $\begin{array}{l}0.0121 \\
(0.009)\end{array}$ & $\begin{array}{c}0.0277 * * * \\
(0.001)\end{array}$ \\
\hline Experience squared & $\begin{array}{c}-0.0005^{* *} \\
(0.000) \\
\end{array}$ & $\begin{array}{c}-0.0005 * * * \\
(0.000)\end{array}$ \\
\hline Experience $\mathrm{x}$ time & $\begin{array}{c}0.0011^{* * *} \\
(0.000)\end{array}$ & $\begin{array}{l}0.0001 * * * \\
(0.000)\end{array}$ \\
\hline IHS-transformed number of R\&D tasks & $\begin{array}{l}0.0488 \\
(0.046)\end{array}$ & $\begin{array}{c}0.0437 * * * \\
(0.005)\end{array}$ \\
\hline $\begin{array}{l}\text { Span of control (IHS-transformed \# of individuals directly } \\
\text { supervised) }\end{array}$ & $\begin{array}{l}0.0498^{*} \\
(0.029)\end{array}$ & $\begin{array}{c}0.0466 * * * \\
(0.002)\end{array}$ \\
\hline $\begin{array}{l}\text { Depth of hierarchy (IHS-transformed \# of individuals } \\
\text { indirectly supervised) }\end{array}$ & $\begin{array}{c}0.0820 * * * \\
(0.024)\end{array}$ & $\begin{array}{c}0.0461 * * * \\
(0.003)\end{array}$ \\
\hline Constant & $\begin{array}{c}10.0238 * * * \\
(0.455)\end{array}$ & $\begin{array}{c}10.5638 * * * \\
(0.042)\end{array}$ \\
\hline $\begin{array}{l}\text { Other controls: gender, ethnicity, occupation, U.S. state of } \\
\text { employment }\end{array}$ & Included & Included \\
\hline Observations & 2,101 & 65,485 \\
\hline R-squared & 0.138 & 0.221 \\
\hline
\end{tabular}

Estimation method: OLS. Robust standard errors in parentheses. ***,**, and * denote statistical significance at the 1 percent, 5 percent, and 10 percent levels, respectively. Because there are observations with zero numbers of R\&D-related work activities as well as a zero span of control and depth of hierarchy, we use inverse hyperbolic sine (IHS) transformations, defined as $y=\ln \left(x+\sqrt{x^{2}+1}\right)$. 


\section{Online Appendix \\ Declining Business Dynamism Among Our Best Opportunities: \\ The Role of the Burden of Knowledge}

\section{Appendix I: Further description of the data set}

SDR. The Survey of Doctorate Recipients (SDR) gathers information from a representative sample of individuals who obtained a doctorate in science or engineering from a US PhD-granting institution, conducted every two to three years. It is a longitudinal survey that follows respondents until age 76, and at each observation point, new $\mathrm{PhD}$ recipients are added while some previously followed individuals are dropped (because of their age or for other reasons). A significant number of individuals were followed over the period from 1993 to 2013, but the sample was almost entirely redrawn in 2015. See http://www.nsf.gov/statistics/srvydoctoratework/ for a detailed description of the target populations and other technical information about SDR.

Startup. The SDR questionnaire classifies individuals as working for startups (new businesses) if they affirmatively answered the question "Did your principal employer come into being as a new business within the past 5 years?" This question was asked in eight surveys, those conducted in 1997 , 1999, 2001, 2003, 2010, 2013, 2015, and 2017.

Sample. We use restricted-use SDR data (available through NSF [National Science Foundation] licensing process) from the 1995, 1997, 1999, 2001, 2003, 2006, 2008, 2010, 2013, 2015, and 2017 surveys, all of which are currently available with exception of the 1993 survey, which does not contain some key information (e.g., whether the respondent worked full time). For the analysis of startups, we use eight surveys in which this question was asked, as noted above. We restrict the sample to doctorate recipients who resided in the U.S. and reported being employed full time (defined as 48 weeks or more per year and 30 hours or more per week) with non-zero salaries, whose principal employer was either a private-sector for-profit company or organization or who were self-employed or business owners in their own (incorporated or non-incorporated) businesses. We exclude all retirees and those working part time or not drawing positive salaries, as well as those employed outside the private-sector for-profit sector. SDR surveys provide weights on individual observations to recover population numbers, and we employ those weights in calculating all the summary statistics and in regression analysis. As mentioned in the main text, using unweighted observations leads to very similar results. Table A1 provides the number of observations in the samples that are used in the main text. 
Table A1. Sample number of observations and their distribution across surveys

\begin{tabular}{|r|r|r|r|r|r|r|}
\hline & \multicolumn{2}{|c|}{ Founders } & \multicolumn{2}{c|}{ Workers at startups } & \multicolumn{2}{c|}{ Workers at established firms } \\
\hline & Unweighted & \multicolumn{1}{c|}{ Weighted } & Unweighted & \multicolumn{1}{c|}{ Weighted } & Unweighted & Weighted \\
\hline 1997 & 177 & 2,971 & 966 & 16,199 & 7,359 & 121,885 \\
\hline 1999 & 150 & 3,111 & 841 & 16,493 & 6,850 & 137,897 \\
\hline 2001 & 128 & 2,903 & 1,192 & 23,795 & 6,696 & 139,754 \\
\hline 2003 & 229 & 5,433 & 627 & 14,770 & 5,656 & 131,493 \\
\hline 2010 & 234 & 6,217 & 506 & 13,701 & 5,964 & 158,632 \\
\hline 2013 & 208 & 5,828 & 455 & 13,078 & 5,852 & 167,431 \\
\hline 2015 & 465 & 6,746 & 991 & 15,802 & 12,858 & 193,087 \\
\hline 2017 & 510 & 6,967 & 1,289 & 17,509 & 14,254 & 195,057 \\
\hline & 2,101 & 40,176 & 6,867 & 131,347 & 65,489 & $1,245,235$ \\
\hline Total & & & &
\end{tabular}

Source: National Science Foundation data.

Work activities: In each survey the respondents were asked to check all work activities that occupied at least 10 percent of their time in a typical week on the job. Table A2 presents the list and more detailed description of all work activities and the number of individuals among founders and workers at established firms who checked the respective boxes. The first four activities listed (basic research, applied research, development, and design) are $R \& D$ activities in the definition used in this paper; the next five activities are management activities.

Table A2. Work activities

\begin{tabular}{|c|c|c|c|c|c|}
\hline \multirow{2}{*}{$\begin{array}{c}\text { SDR abbreviation } \\
\text { and name }\end{array}$} & \multirow{2}{*}{ Description of work activity } & \multicolumn{2}{|c|}{ Founders } & \multicolumn{2}{|c|}{ Workers at established firms } \\
\hline & & Unweighted & Weighted & Unweighted & Weighted \\
\hline $\begin{array}{l}\text { WABRSH - } \\
\text { Basic research }\end{array}$ & $\begin{array}{l}\text { Study aims to gain scientific knowledge for } \\
\text { its own sake }\end{array}$ & 419 & 8,012 & 16,827 & 319,956 \\
\hline $\begin{array}{l}\text { WAAPRSH- } \\
\text { Applied research }\end{array}$ & $\begin{array}{l}\text { Study aims to gain scientific knowledge to } \\
\text { meet a recognized need }\end{array}$ & 1,108 & 21,188 & 44,185 & 840,152 \\
\hline $\begin{array}{l}\text { WADEV- } \\
\text { Development }\end{array}$ & $\begin{array}{l}\text { Using knowledge gained from research for } \\
\text { the production of materials and devices }\end{array}$ & 1,043 & 19,945 & 39,521 & 751,469 \\
\hline $\begin{array}{l}\text { WADSN- } \\
\text { Design }\end{array}$ & $\begin{array}{l}\text { Design of equipment, processes, structures, } \\
\text { and models }\end{array}$ & 821 & 15,699 & 30,047 & 571,326 \\
\hline $\begin{array}{l}\text { WAACC-Accounting, } \\
\text { finance, contracts }\end{array}$ & Accounting, finance, contracts & 1,110 & 21,226 & 12,607 & 239,715 \\
\hline $\begin{array}{l}\text { WAEMRL- } \\
\text { Human resources }\end{array}$ & $\begin{array}{l}\text { Including recruiting, personnel development, } \\
\text { training }\end{array}$ & 686 & 13,118 & 17,335 & 329,615 \\
\hline $\begin{array}{l}\text { WAMGMT- } \\
\text { Management }\end{array}$ & Managing or supervising people on projects & 1,366 & 26,121 & 41,766 & 794,156 \\
\hline $\begin{array}{l}\text { WAQM- } \\
\text { Quality management }\end{array}$ & Quality or productivity management & 587 & 11,225 & 15,379 & 292,423 \\
\hline $\begin{array}{l}\text { WASALE- } \\
\text { Sales }\end{array}$ & $\begin{array}{l}\text { Sales, purchasing, marketing, customer } \\
\text { service, public relations }\end{array}$ & 994 & 19,008 & 12,931 & 245,875 \\
\hline $\begin{array}{l}\text { WAPROD- } \\
\text { Production }\end{array}$ & $\begin{array}{l}\text { Production, operations, maintenance (e.g., } \\
\text { chip production, operating lab equipment) }\end{array}$ & 302 & 5,775 & 8,729 & 165,977 \\
\hline $\begin{array}{l}\text { WASVC- } \\
\text { Professional Services }\end{array}$ & $\begin{array}{l}\text { Professional services (e.g., health care, } \\
\text { counseling, financial services, legal services) }\end{array}$ & 952 & 18,204 & 10,933 & 207,885 \\
\hline $\begin{array}{l}\text { WACOM- } \\
\text { Computer applications }\end{array}$ & $\begin{array}{l}\text { Computer programming, systems, or } \\
\text { applications development }\end{array}$ & 736 & 14,074 & 25,027 & 475,874 \\
\hline $\begin{array}{l}\text { WATEA- } \\
\text { Teaching }\end{array}$ & Teaching & 400 & 7,649 & 7,121 & 135,402 \\
\hline $\begin{array}{l}\text { WAOT- } \\
\text { Other }\end{array}$ & Other & 141 & 2,696 & 4,130 & 78,530 \\
\hline
\end{tabular}

Source: National Science Foundation data. 


\section{Appendix II: Supporting analysis}

\section{A. Decline in startup formation and demographics}

We present four figures that split the sample by gender and white/non-white race as well as a figure that limits the sample to $\mathrm{PhDs}$ employed in California. The levels are different, but time trends are very similar to those observed in Figure 1. California, in particular, exhibits a decline in the rate of startups as large as that in the rest of the country (cf. Decker et al., 2014).

Figure A1. Dynamics of the share of male PhDs employed at or founders of startups

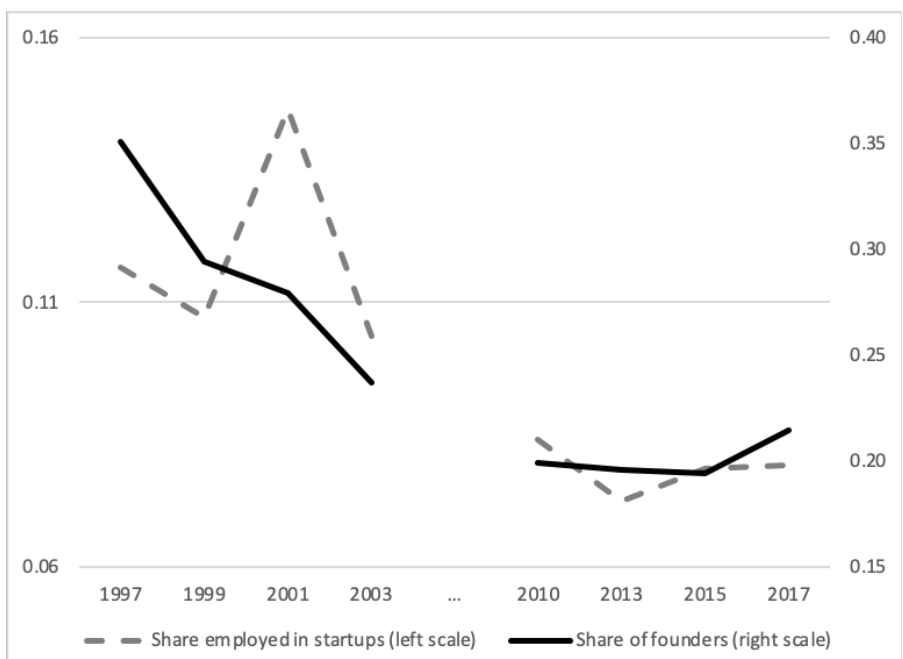

Source: Author calculations using weighted National Science Foundation data.

Figure A2. Dynamics of the share of female PhDs employed at or founders of startups

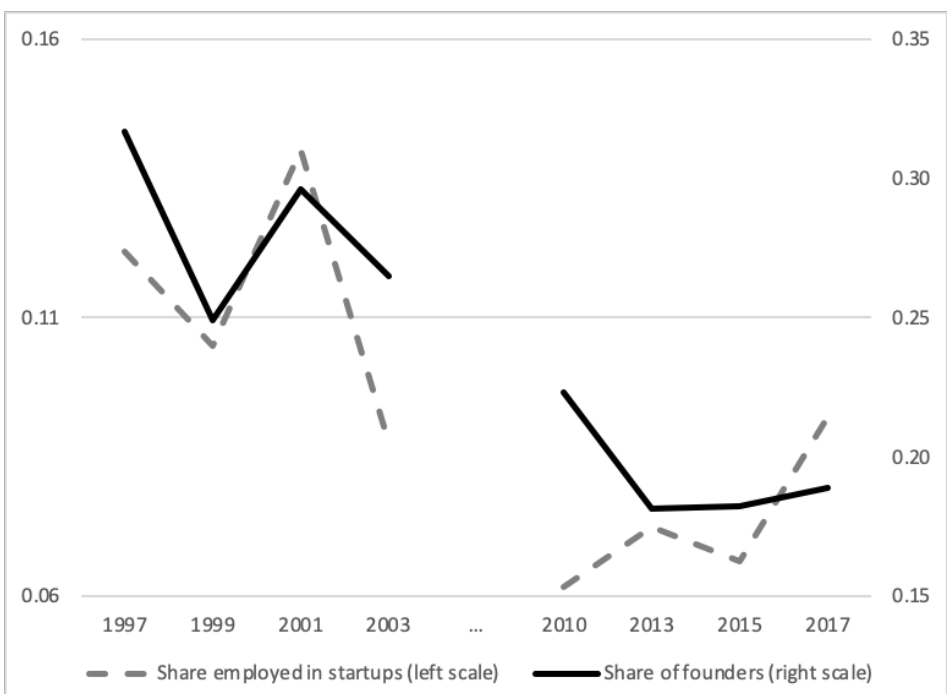

Source: Author calculations using weighted National Science Foundation data. 
Figure A3. Dynamics of the share of white PhDs employed at or founders of startups

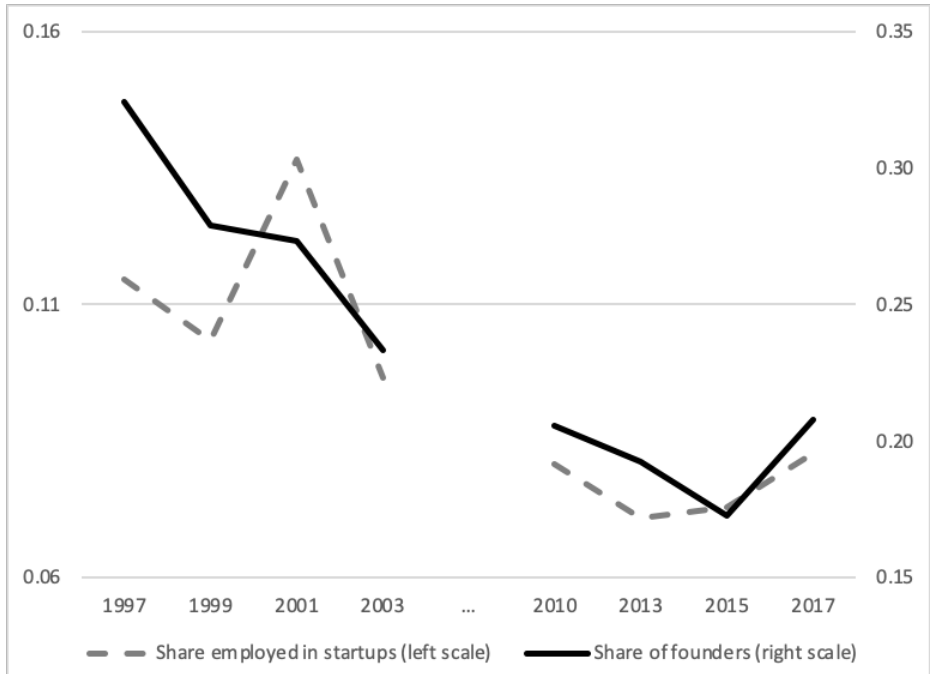

Source: Author calculations using weighted National Science Foundation data.

Figure A4. Dynamics of the share of non-white PhDs employed at or founders of startups

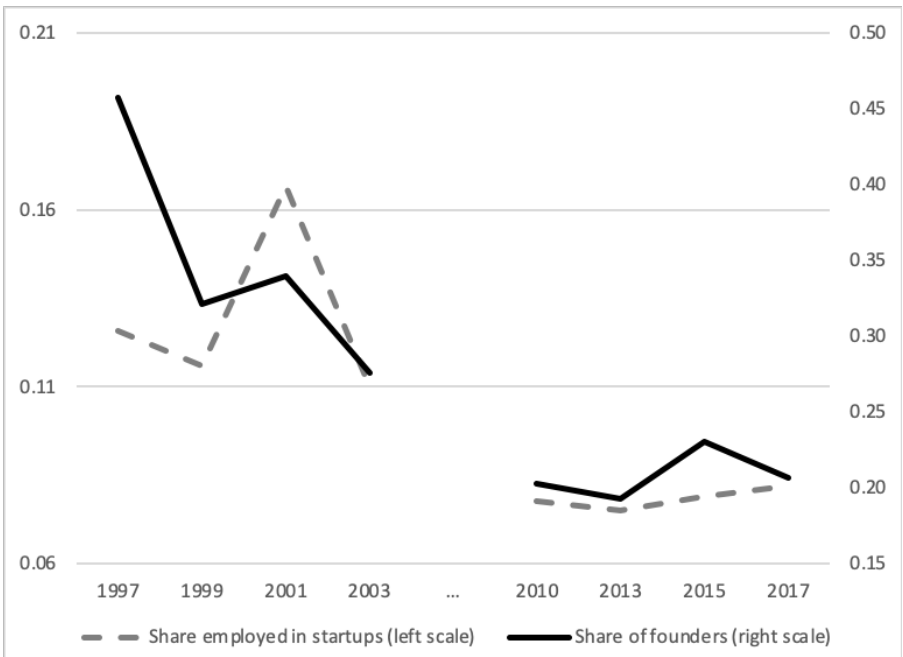

Source: Author calculations using weighted National Science Foundation data.

Figure A5. Dynamics of the share of PhDs residing in California employed at or founders of startups

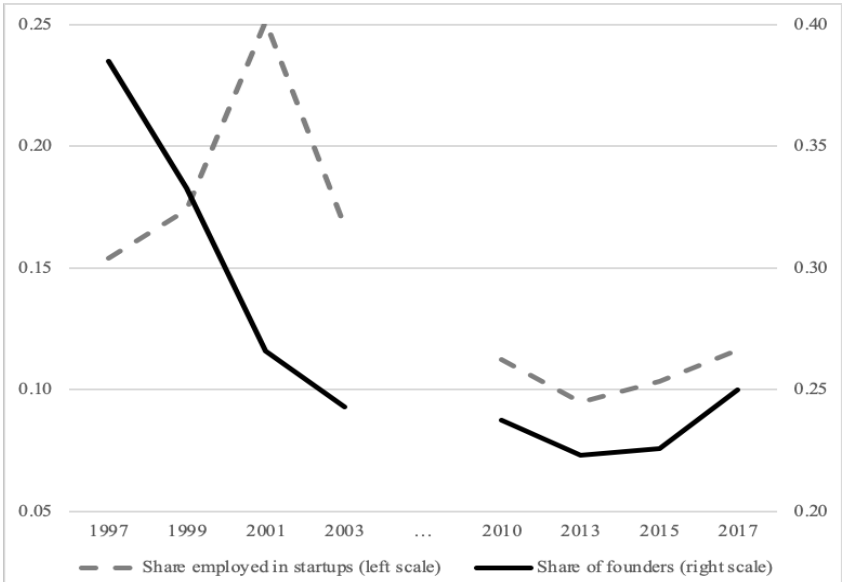

Source: Author calculations using weighted National Science Foundation data. 
Figure A6. Dynamics of the share of non-U.S. born PhDs employed at or founders of startups

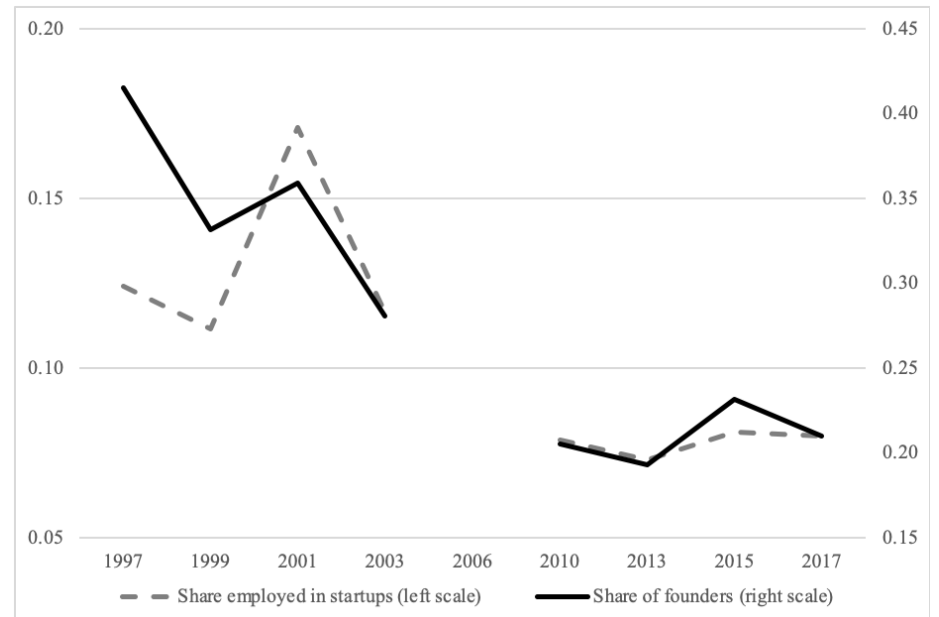

Source: Author calculations using weighted National Science Foundation data.

\section{B. Age at which the $\mathrm{PhD}$ is received}

In Figure A7 we plot the dynamics of the age at which individuals received their PhDs. Sample attrition in this case causes those with $\mathrm{PhDs}$ received in earlier years to drop out of the sample at a higher rate than those who received their $\mathrm{PhDs}$ later, so, rather than pooling all observations, we look at pictures at two points in time, using the 1997 and 2017 surveys. We also limit the sample in each case to those who received their $\mathrm{PhD}$ within the 25 years preceding the cutoff year of observations and between ages 20 and 40, to avoid going past the common retirement age.

Figure A7. Average age when the $\mathrm{PhD}$ is received

Panel A. 1971-1995 PhD recipients in the 1997 survey

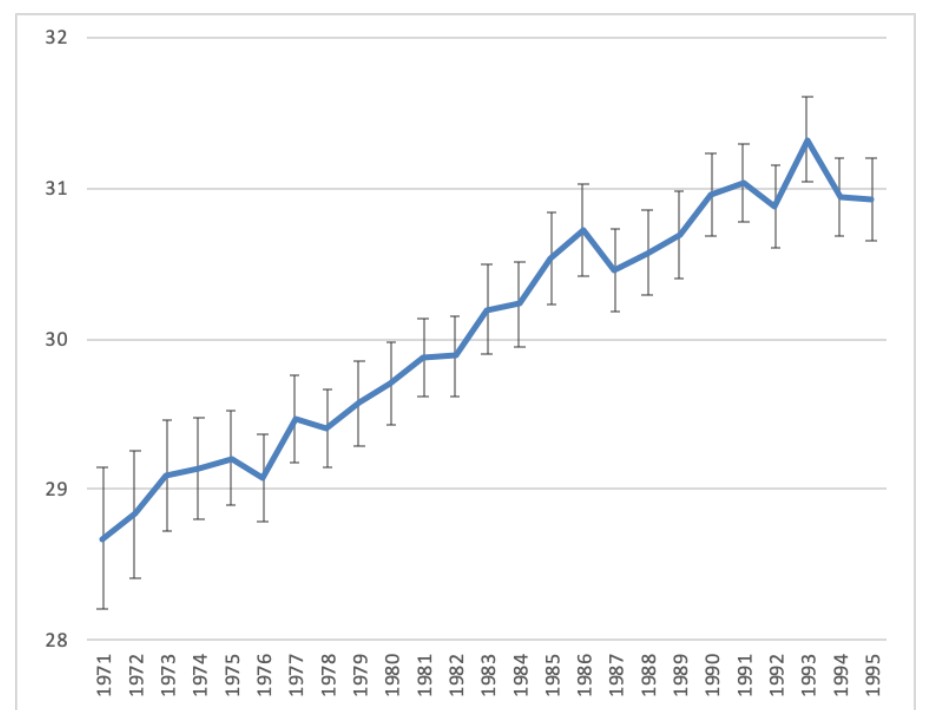

Source: Author calculations using National Science Foundation data. Bars represent 95 percent confidence intervals. 
Panel B. 1991-2015 PhD recipients in the 2017 survey

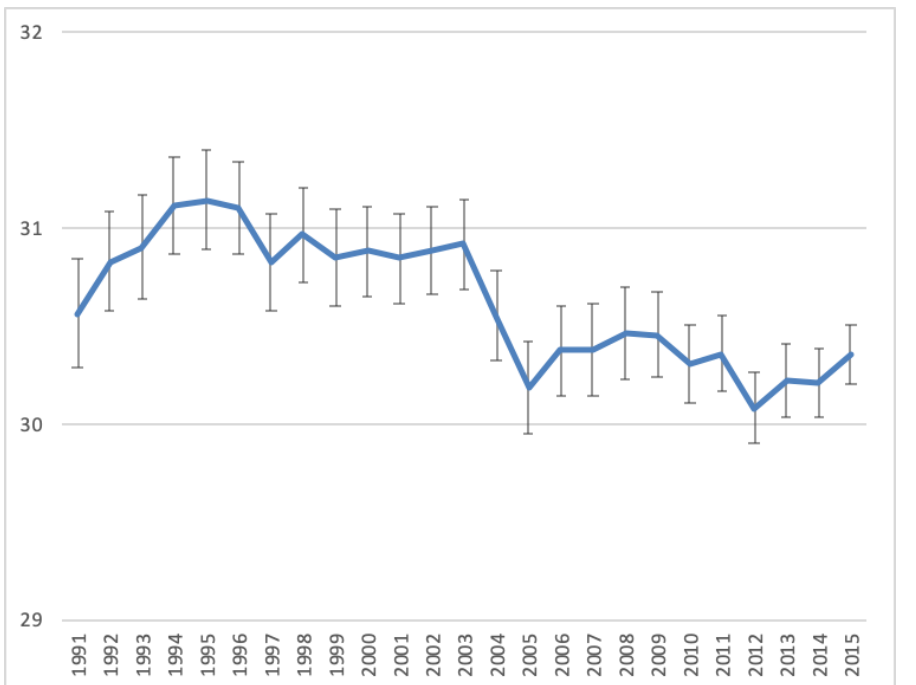

Source: Author calculations using National Science Foundation data. Bars represent 95 percent confidence intervals.

Both Panels A and B (as well as in other years, not shown) show that the average age at which $\mathrm{PhDs}$ are received had been increasing until around 1993. Average $\mathrm{PhD}$ recipients were about 2.6 years older in 1993 than they were in 1971. Starting in the mid-1990s, however, the average age of receiving a $\mathrm{PhD}$ is flat or even declining.

\section{Inflation-adjusted annual earnings of founders and workers at established firms}

Table A3 presents the dynamics of inflation-adjusted real earnings of founders and workers at established firms. Consistent with Figure 2 in the main text and the regression estimation results in Table 2, we can see that earnings of less experienced founders are declining not just in relative but also in absolute terms. Both more and less experienced workers at established firms, by contrast, increase their earnings over time, as do also more experienced founders.

Table A3. Annual real earnings of founders and of workers at established firms (in US \$)

\begin{tabular}{|c|c|c|c|c|c|c|}
\hline & \multicolumn{3}{|c|}{ Founders } & \multicolumn{3}{c|}{ Workers at established firms } \\
\hline Survey Year & All & $\begin{array}{c}\leq 13 \text { years after } \\
\text { PhD }\end{array}$ & $\begin{array}{c}>13 \text { years after } \\
\text { PhD }\end{array}$ & All & $\begin{array}{c}\leq 13 \text { years after } \\
\text { PhD }\end{array}$ & $\begin{array}{c}>13 \text { years after } \\
\text { PhD }\end{array}$ \\
\hline 1997 & 71,094 & 72,616 & 69,958 & 79,509 & 66,375 & 91,846 \\
\hline 1999 & 81,310 & 81,853 & 80,909 & 80,006 & 68,261 & 92,460 \\
\hline 2001 & 76,401 & 80,781 & 70,676 & 83,823 & 73,496 & 95,248 \\
\hline 2003 & 87,278 & 80,691 & 93,398 & 84,812 & 74,579 & 96,936 \\
\hline 2010 & 86,353 & 71,464 & 100,780 & 88,469 & 76,078 & 100,849 \\
\hline 2013 & 84,572 & 63,165 & 98,453 & 87,074 & 73,614 & 98,341 \\
\hline 2015 & 77,656 & 61,734 & 88,001 & 90,762 & 76,252 & 102,370 \\
\hline 2017 & 80,422 & 57,517 & 98,690 & 88,554 & 75,052 & 100,890 \\
\hline
\end{tabular}

Source: Author calculations using weighted National Science Foundation data. Salary data were adjusted for inflation using consumer price index. Thirteen years after $\mathrm{PhD}$ corresponds the median post-PhD experience in the sample. 


\section{The number of R\&D tasks, span of control, and depth of the hierarchy at large firms}

In this section we repeat the estimations presented in Table 1 but for the sample limited to workers at the largest firms. SDR surveys contain responses to the question about broadly defined size categories of the employers, measured by the responders' estimates of how many people worked for the principal employer across all locations. There are eight categories, ranging from 10 or fewer employees to $25,000+$ employees. For the purpose of this analysis, we define firms in the two largest categories, 5,000-24,999 employees and 25,000+ employees, as "large firms." In columns (1), (3), and (5), we present estimation results from eight surveys in which the question about employer age was asked, so the sample is limited to employees at large firms that we know are not startups. In columns (2), (4), and (6), we employ data from all 11 available surveys under the assumption that firms with 5,000 or more employees are highly unlikely to be startups. Results from all surveys and from the eight surveys where we know firm age are very similar.

Comparing the estimation results in Table A4 to those in Table 1 pertaining to workers at all established firms, we notice that the coefficient on the time trend variable in the number of R\&D tasks is smaller among workers at large firms compared with all workers and is about half the magnitude of the corresponding coefficient for founders in column (1) of Table 1. Thus, workers at large firms face an increase in the burden of knowledge at about half the pace of founders. Perhaps even more interestingly, the coefficient on the time variable in the regression where the dependent variable is the depth of the hierarchy is twice the magnitude of the coefficient in the same regression for the sample of all workers at established firms in Table 1. It appears that to offset the increasing burden of knowledge, large firms create deeper hierarchies over time, and this allows them to implement a greater division of labor.

Table A4.

Panel A. Factors affecting the number of R\&D tasks for employees at large firms.

\begin{tabular}{|l|c|c|}
\hline & \multicolumn{2}{|c|}{ DV: IHS-transformed number of R\&D tasks } \\
\hline & $(1)$ & $(2)$ \\
& Workers at large established & firms \\
& $0.0057^{* * *}$ & Workers at all large firms \\
\hline \multirow{2}{*}{ Time } & $(0.001)$ & $0.0045^{* * *}$ \\
& $-0.0048^{* * *}$ & $(0.000)$ \\
\hline \multirow{2}{*}{ Experience (years after PhD) } & $(0.000)$ & $-0.0051^{* * *}$ \\
& $1.0095^{* * *}$ & $(0.000)$ \\
\hline \multirow{2}{*}{ Constant } & $(0.073)$ & $1.0372^{* * *}$ \\
& Included & $(0.063)$ \\
\hline Other controls: gender, ethnicity, & 36,115 & Included \\
occupation, U.S. state of employment & 0.226 & 47,987 \\
\hline Observations & & 0.222 \\
\hline R-squared & & \\
\hline
\end{tabular}


Panel B. Factors affecting the span of control and depth of the hierarchy

\begin{tabular}{|c|c|c|c|c|}
\hline & \multicolumn{2}{|c|}{$\begin{array}{c}\text { DV: span of control (IHS- } \\
\text { transformed \# of individuals directly } \\
\text { supervised) }\end{array}$} & \multicolumn{2}{|c|}{$\begin{array}{l}\text { DV: depth of hierarchy (IHS- } \\
\text { transformed \# of individuals } \\
\text { indirectly supervised) }\end{array}$} \\
\hline & $\begin{array}{l}\text { (3) } \\
\text { Workers at large } \\
\text { established } \\
\text { firms }\end{array}$ & $\begin{array}{l}\text { (4) } \\
\text { Workers at all } \\
\text { large firms }\end{array}$ & $\begin{array}{l}\text { (5) } \\
\text { Workers at large } \\
\text { established } \\
\text { firms }\end{array}$ & $\begin{array}{l}(6) \\
\text { Workers at all } \\
\text { large firms }\end{array}$ \\
\hline Time & $\begin{array}{c}-0.0036^{* * * *} \\
(0.001) \\
\end{array}$ & $\begin{array}{c}-0.0028^{* * *} \\
(0.001)\end{array}$ & $\begin{array}{c}0.0065^{* * *} \\
(0.001)\end{array}$ & $\begin{array}{c}0.0065^{* * *} \\
(0.001)\end{array}$ \\
\hline Experience (years after $\mathrm{PhD}$ ) & $\begin{array}{c}0.0077 * * * \\
(0.001)\end{array}$ & $\begin{array}{c}0.0063 * * * \\
(0.001)\end{array}$ & $\begin{array}{c}0.0117^{* * *} \\
(0.001)\end{array}$ & $\begin{array}{c}0.0099 * * * \\
(0.001)\end{array}$ \\
\hline Constant & $\begin{array}{c}0.6277 * * * \\
(0.130)\end{array}$ & $\begin{array}{c}0.6230^{* * *} \\
(0.113)\end{array}$ & $\begin{array}{r}-0.1227 \\
(0.158) \\
\end{array}$ & $\begin{array}{l}-0.0877 \\
(0.131) \\
\end{array}$ \\
\hline $\begin{array}{l}\text { Other controls: gender, ethnicity, } \\
\text { occupation, U.S. state of employment }\end{array}$ & Included & Included & Included & Included \\
\hline Observations & 36,115 & 47,987 & 36,115 & 47,987 \\
\hline R-squared & 0.210 & 0.222 & 0.489 & 0.502 \\
\hline
\end{tabular}

\section{E. Type of entrepreneurial opportunity}

In the main text, we limited our sample of founders to owners of new incorporated businesses. As mentioned, this was motivated by our desire to focus on the most innovative and entrepreneurial portion of the sample of business owners and the self-employed. Past research (see Braguinsky, Klepper, and Ohyama, 2012; Ohyama, 2015) has employed the relation between the job and the highest degree as an alternative proxy for entrepreneurs in these data. SDR surveys contain answers to the question about this relationship, with possible answers being "closely related," "somewhat related," and "not related at all." Following the methodology in those studies, we constructed a dummy that equals one if the answer was "closely related" and zero otherwise, and we call such business owners/self-employed in new businesses "education-job related" (EJR) founders, regardless of whether their businesses were incorporated. About half the self-employed and business owners and also founders in the sample fall into this category.

In Table A5 we repeated the estimations of equation (1) on the sample of EJR founders, whether their firm was incorporated or not. The number of R\&D tasks exhibits a positive time trend that is very similar in magnitude to the sample of incorporated startup founders in Table 1, Column (1). EJR founders have to cope with a number of R\&D tasks that are, once again, increasing over time at twice the rate experienced by workers at large, established firms (Table A4). However, we see that in this case, the time trend is offset by experience (years after $\mathrm{PhD}$ ), meaning that more experienced EJR founders tend to perform fewer R\&D tasks over time. Like the founders in the main sample, EJR founders on average do not have recourse to deeper hierarchies, and while the coefficient on time trend in the regression with the span of control as the outcome variable is estimated to be positive, it is only marginally statistically significant. 
Table A5. The number of R\&D tasks, the span of control, and the depth of the hierarchy for EJR founders

\begin{tabular}{|c|c|c|c|}
\hline DV: & $\begin{array}{c}\text { IHS-transformed } \\
\text { number of R\&D } \\
\text { tasks }\end{array}$ & $\begin{array}{l}\text { IHS-transformed } \\
\text { span of control }\end{array}$ & $\begin{array}{l}\text { IHS-transformed } \\
\text { depth of hierarchy }\end{array}$ \\
\hline Time & $\begin{array}{c}0.0103 * * * \\
(0.002)\end{array}$ & $\begin{array}{l}0.0061 * \\
(0.003)\end{array}$ & $\begin{array}{l}-0.0015 \\
(0.003) \\
\end{array}$ \\
\hline Experience (years after $\mathrm{PhD}$ ) & $\begin{array}{c}-0.0050 * * * \\
(0.002)\end{array}$ & $\begin{array}{c}-0.0046^{*} \\
(0.002)\end{array}$ & $\begin{array}{l}0.0012 \\
(0.003) \\
\end{array}$ \\
\hline Constant & $\begin{array}{c}1.1084 * * * \\
(0.216)\end{array}$ & $\begin{array}{l}0.7942 * \\
(0.446) \\
\end{array}$ & $\begin{array}{l}0.6389 \\
(0.393) \\
\end{array}$ \\
\hline $\begin{array}{l}\text { Other controls: gender, ethnicity, } \\
\text { occupation, U.S. state of employment }\end{array}$ & Included & Included & Included \\
\hline Observations & 2,093 & 2,093 & 2,093 \\
\hline R-squared & 0.478 & 0.257 & 0.317 \\
\hline
\end{tabular}

Estimation method: OLS. ***,**, and * denote statistical significance at the 1 percent, 5 percent, and 10 percent levels, respectively.

Table A6. Earnings of EJR founders

\begin{tabular}{|c|c|}
\hline DV: & Log (real earnings) \\
\hline Time & $\begin{array}{c}-0.0119^{* * *} \\
(0.004)\end{array}$ \\
\hline Experience (years after PhD) & $\begin{array}{c}0.0169^{* *} \\
(0.007)\end{array}$ \\
\hline Experience squared & $\begin{array}{c}-0.0005^{* *} \\
(0.000)\end{array}$ \\
\hline Experience $\mathrm{x}$ time & $\begin{array}{c}0.0008^{* * *} \\
(0.000)\end{array}$ \\
\hline IHS-transformed number of R\&D tasks & $\begin{array}{l}-0.0499 \\
(0.035)\end{array}$ \\
\hline Span of control (IHS-transformed \# of individuals directly supervised) & $\begin{array}{c}0.0827^{* * *} \\
(0.024) \\
\end{array}$ \\
\hline Depth of hierarchy (IHS-transformed \# of individuals indirectly supervised) & $\begin{array}{c}0.0651 * * * \\
(0.021)\end{array}$ \\
\hline Constant & $\begin{array}{c}11.0642 * * * \\
(0.255)\end{array}$ \\
\hline Other controls: gender, ethnicity, occupation, U.S. state of employment & Included \\
\hline Observations & 2,093 \\
\hline R-squared & 0.236 \\
\hline
\end{tabular}

Estimation method: OLS. ${ }^{* * *}, * *$, and $*$ denote statistical significance at the 1 percent, 5 percent, and 10 percent levels, respectively.

In Table A6 we report the results of the earnings regression on EJR founders. Overall, the estimations look similar to those presented for incorporated founders in Table 2. There is a declining time trend for earnings for EJR founders of about 1.2 percent per year at the baseline. This decline is offset by the interaction between the time trend and work experience. Given the mean years after $\mathrm{PhD}$ of 14.2 years in this sample, the negative time trend is almost but not completely offset by experience at the mean number of years after $\mathrm{PhD}$. As in Table 2, it can be seen that EJR founders are not compensated for performing more $R \& D$ tasks over time. The point estimate is even negative in this 
sample. The span of control and the depth of the hierarchy are both positively associated with earnings, just as in the sample of incorporated founders. Overall, results presented in the main text can be seen to be robust to use of this alternative definition of Schumpeterian firms.

\section{F. R\&D-focused founders}

Table A7 presents the dynamics of the share of R\&D-focused founders, owners of established incorporated businesses, and workers at established firms in the total number of individuals in each category, as well as the share of R\&D-focused owners of all incorporated businesses and of R\&Dfocused workers at all large firms, using all available surveys. Founders and owners in charge of their own businesses on average are less likely to be R\&D-focused than workers, but there is an increasing trend over time that is even more pronounced among all owners than it is among founders. Using the most comprehensive data from all surveys, column (3) reports that the share of R\&D-focused owners of incorporated businesses almost doubles from the mid-1990s to the mid-2010s. The share of R\&Dfocused workers at established firms, in contrast, remains stable and even appears to decline slightly in the sample of all workers at large firms.

Table A7. Shares of R\&D-focused founders and workers

\begin{tabular}{|c|c|c|c|c|c|}
\hline & $\begin{array}{c}(1) \\
\text { Founders }\end{array}$ & $\begin{array}{c}(2) \\
\text { Owners of established } \\
\text { incorporated businesses }\end{array}$ & $\begin{array}{c}(3) \\
\text { Owners of all } \\
\text { incorporated businesses }\end{array}$ & $\begin{array}{c}(4) \\
\text { Workers at } \\
\text { established firms }\end{array}$ & $\begin{array}{c}(5) \\
\text { Workers at all } \\
\text { large firms }\end{array}$ \\
\hline 1995 & & & 0.178 & & 0.600 \\
1997 & 0.261 & 0.118 & 0.167 & 0.509 & 0.586 \\
1999 & 0.288 & 0.150 & 0.189 & 0.520 & 0.598 \\
2001 & 0.316 & 0.157 & 0.202 & 0.508 & 0.578 \\
2003 & 0.359 & 0.297 & 0.312 & 0.512 & 0.555 \\
2006 & & & 0.309 & & 0.545 \\
2008 & & 0.288 & & 0.566 \\
2010 & 0.309 & 0.279 & 0.285 & 0.524 & 0.561 \\
2013 & 0.308 & 0.285 & 0.289 & 0.503 & 0.531 \\
2015 & 0.373 & 0.287 & 0.303 & 0.512 & 0.553 \\
2017 & 0.316 & 0.328 & 0.325 & 0.517 & 0.547 \\
\hline
\end{tabular}

Source: Author calculations using weighted National Science Foundation data.

In Table A8 we present the results of earnings regressions on the sample of R\&D-focused founders and R\&D-focused workers at established firms. As discussed in the main text, the trend toward declining earnings is much stronger in this subsample of founders, although the offsetting impact of the interaction term between experience is also stronger, implying that at the mean of years after $\mathrm{PhD}$, the baseline negative time trend is more or less offset. As for R\&D-focused workers, some coefficients are somewhat smaller in magnitude than for the full sample but, overall, the results look similar. 
Table A8. Earnings of R\&D-focused founders and workers at established firms

\begin{tabular}{|c|c|c|}
\hline DV: Log (real earnings) & & \\
\hline & $\begin{array}{l}(1) \\
\text { Founders }\end{array}$ & $\begin{array}{c}(2) \\
\text { Workers at } \\
\text { established firms }\end{array}$ \\
\hline Time & $\begin{array}{c}-0.0445 * * * \\
(0.012)\end{array}$ & $\begin{array}{c}0.0027^{* * *} \\
(0.001)\end{array}$ \\
\hline Experience (years after $\mathrm{PhD}$ ) & $\begin{array}{r}-0.0161 \\
(0.013) \\
\end{array}$ & $\begin{array}{c}0.0293 * * * \\
(0.001)\end{array}$ \\
\hline Experience squared & $\begin{array}{l}-0.0003 \\
(0.000)\end{array}$ & $\begin{array}{c}-0.0005 * * * \\
(0.000)\end{array}$ \\
\hline Experience $\mathrm{x}$ time & $\begin{array}{c}0.0026^{* * *} \\
(0.001)\end{array}$ & $\begin{array}{c}0.0001^{* * *} \\
(0.000)\end{array}$ \\
\hline IHS-transformed number of R\&D tasks & $\begin{array}{l}-0.1521 \\
(0.123)\end{array}$ & $\begin{array}{l}0.0326^{* * *} \\
(0.009)\end{array}$ \\
\hline $\begin{array}{l}\text { Span of control (IHS-transformed \# of individuals directly } \\
\text { supervised) }\end{array}$ & $\begin{array}{c}0.1109 * * \\
(0.054)\end{array}$ & $\begin{array}{c}0.0372^{* * *} \\
(0.003)\end{array}$ \\
\hline $\begin{array}{l}\text { Depth of hierarchy (IHS-transformed \# of individuals } \\
\text { indirectly supervised) }\end{array}$ & $\begin{array}{l}0.0549 \\
(0.044)\end{array}$ & $\begin{array}{c}0.0364 * * * \\
(0.004)\end{array}$ \\
\hline Constant & $\begin{array}{c}11.9358 * * * \\
(0.477)\end{array}$ & $\begin{array}{c}10.7582^{* * *} \\
(0.048)\end{array}$ \\
\hline Other controls: gender, ethnicity, occupation, U.S. state of & Included & Included \\
\hline Observations & 690 & 33,710 \\
\hline R-squared & 0.234 & 0.179 \\
\hline
\end{tabular}

Table A9 presents summary statistics on annual real earnings of R\&D-focused founders and workers at established firms, as in Table A3. Less experienced founders' earnings suffer the biggest decline: these decrease by about 40 percent in the surveys conducted in 2010 s compared to the first four surveys. More experienced founders, as well as workers at established firms (regardless of experience), by contrast, saw a modest upward time trend in their earnings.

Table A9. Annual real earnings of founders and workers at established firms: R\&D-focused (in US \$)

\begin{tabular}{|c|c|c|c|c|c|c|}
\hline & \multicolumn{3}{|c|}{ Founders } & \multicolumn{3}{c|}{ Workers at established firms } \\
\hline Survey Year & All & $\begin{array}{c}\leq 13 \text { years after } \\
\text { PhD }\end{array}$ & $\begin{array}{c}>13 \text { years after } \\
\text { PhD }\end{array}$ & All & $\begin{array}{c}\leq 13 \text { years after } \\
\text { PhD }\end{array}$ & $\begin{array}{c}>13 \text { years after } \\
\text { PhD }\end{array}$ \\
\hline 1997 & 61,606 & 60,568 & 62,116 & 74,012 & 64,877 & 85,417 \\
\hline 1999 & 90,155 & 101,111 & 84,903 & 74,772 & 66,470 & 85,976 \\
\hline 2001 & 89,662 & 116,805 & 70,075 & 78,473 & 69,676 & 89,873 \\
\hline 2003 & 95,880 & 112,174 & 83,704 & 79,895 & 71,083 & 92,675 \\
\hline 2010 & 84,476 & 62,871 & 101,204 & 83,497 & 71,946 & 97,154 \\
\hline 2013 & 86,568 & 66,953 & 97,002 & 82,536 & 70,023 & 94,876 \\
\hline 2015 & 78,855 & 57,662 & 91,375 & 85,262 & 72,856 & 97,517 \\
\hline 2017 & 78,565 & 53,605 & 97,258 & 83,619 & 72,510 & 95,924 \\
\hline
\end{tabular}

Source: Author calculations using weighted National Science Foundation data. Salary data were adjusted for inflation using consumer price index. Thirteen years after $\mathrm{PhD}$ corresponds the median post-PhD experience in the sample. 


\section{G. Human capital}

SDR surveys have a longitudinal aspect, as each new survey between 1995 and 2013 returns to previous survey respondents, and new $\mathrm{PhD}$ recipients are added to every survey. The attrition rate between adjacent surveys is about 10-15 percent. In 2015, however, the survey was sent to an almost entirely new sample of respondents (the attrition rate from the 2013 to the 2015 survey is about 90 percent). Hence, we use two waves of panel data available for founders: the 1997-2013 wave and the 2015-2017 wave.

To estimate changes in the human capital of founders we use the longitudinal aspect of the data and look at all those employed at a private-for-profit business in a survey. We create a dummy that equals one if the individual is reported to be a startup founder in the next survey and zero if he or she remained employed at a private-sector for-profit business in the next survey as well. We then compare these "pre-choice" salaries to obtain an estimate of the human capital differential between future founders and those who remained in paid work for other firms, based on how much they earned while both types of individuals were employed for pay.

Because the demographics are different across future founders and those who remained in paid work for other firms (in particular, the former tend to have more experience than the latter), in Figure A8 we present predicted logged pre-choice salaries from an earnings regression estimated separately on the data from each relevant pre-choice survey $(1995,1997,1999,2001,2008,2010$, and 2015), in which the dependent variable is the pre-choice logged salary, and the explanatory variables are work experience and its squared term, tenure on the current (pre-choice) job, gender and ethnicity dummies, as well as 75 occupation dummies, U.S. state of employment (Massachusetts, New York, California, etc.) dummies, and eight employer size-category dummies. Figure A8 plots these predicted logged pre-choice salaries and the 95 percent confidence intervals.

Figure A8. Predicted logged pre-choice salaries for those becoming startup founders in the next survey and those remaining as wage workers

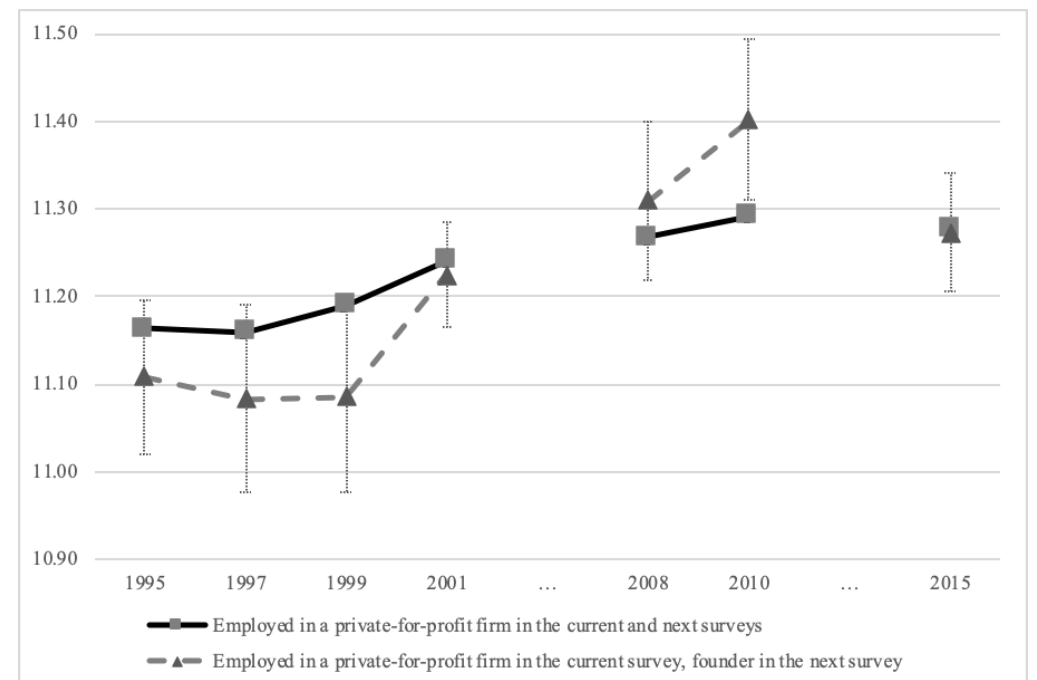

Source: Author estimates based on National Science Foundation data. The bars represent 95 percent confidence intervals. 
As seen in Figure A8, the average predicted earnings of those who become founders in the next survey are lower than the average predicted earnings of those who remain at private sector forprofit businesses in the 1990s but converge in 2001 and exceed those of workers who continue to work for other firms in 2008-2010. Because of the small sample size of founders in these longitudinal data, the 95 percent confidence intervals for the most part overlap. The only time when there is a statistically significant difference at the 5 percent level between predicted pre-choice salaries of these two categories of individuals, in 2010, the pre-choice predicted salaries of future founders are actually higher than those who continue to work for other firms. This suggests that PhDs who left paid employment to start their own incorporated businesses between 2010 and 2013, that is, right after the Great Recession, had significantly higher human capital than those who remained in paid work for others. In any case, the evidence in Figure A8 does not support a decline in the human capital of founders.

For the sake of comparison, Figure A9 presents the same pre-choice salaries but in the raw data. The picture is qualitatively the same, except that the pre-choice salaries of future founders with more experience are not lower than those who remained in paid work for others even in the 1990s.

Figure A9. Actual pre-choice salaries for those becoming startup founders in the next survey and those remaining wage workers

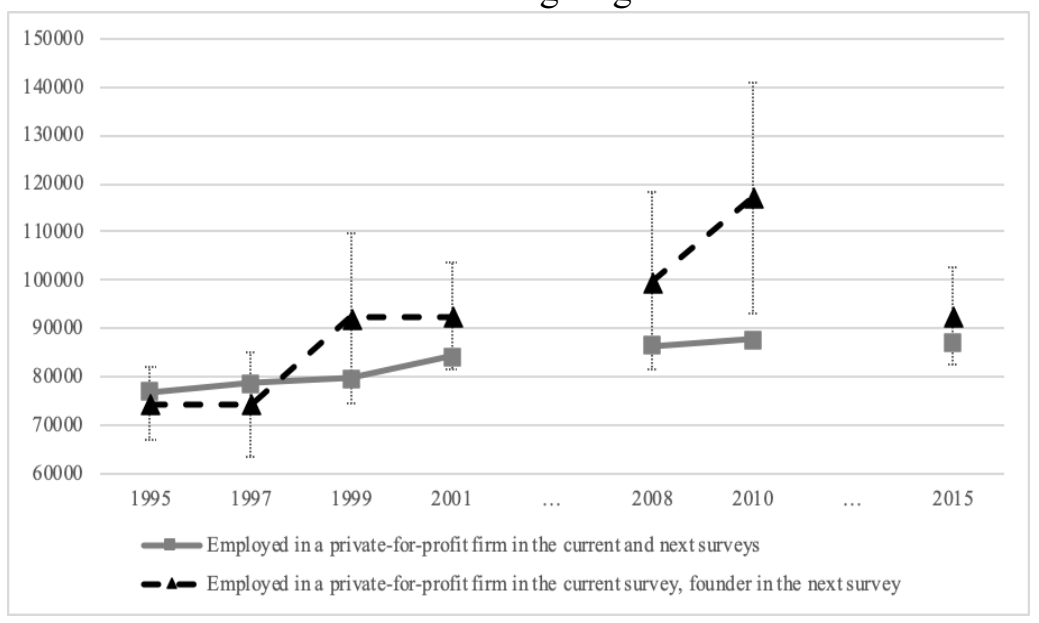

Source: Author calculations using weighted NSF data. The bars represent 95 percent confidence intervals.

In Figure A10 we look at an alternative measure of human capital - the share of individuals who graduated from top-ranked $\mathrm{PhD}$ programs. SDR data contain Integrated Postsecondary Education codes for the institutions from which the respondents graduated and their field of specialization in the graduate program. We matched these codes with the National Research Council (NRC) PhD program rankings published in 1993 and constructed a dummy that equals one if the individual graduated from a $\mathrm{PhD}$-granting institution in the top 15 in the NRC rankings and zero otherwise. We also added to these top-ranked programs graduates whose specific $\mathrm{PhD}$ area was among the top 15 in the NRC's area rankings (the areas were mathematics and physics, engineering, 
social sciences, and biological sciences). Figure A10 is consistent with Figure A8 in showing that founders lag behind in terms of the share graduating from top-ranked programs in the 1990s but catch up to a large degree after 2003. Notably, the catchup trend is even more pronounced among founders with below the median years after $\mathrm{PhD}$, despite the evidence presented that they suffer an increasing earnings penalty over time.

Figure A10. Share of graduates from top-ranked programs

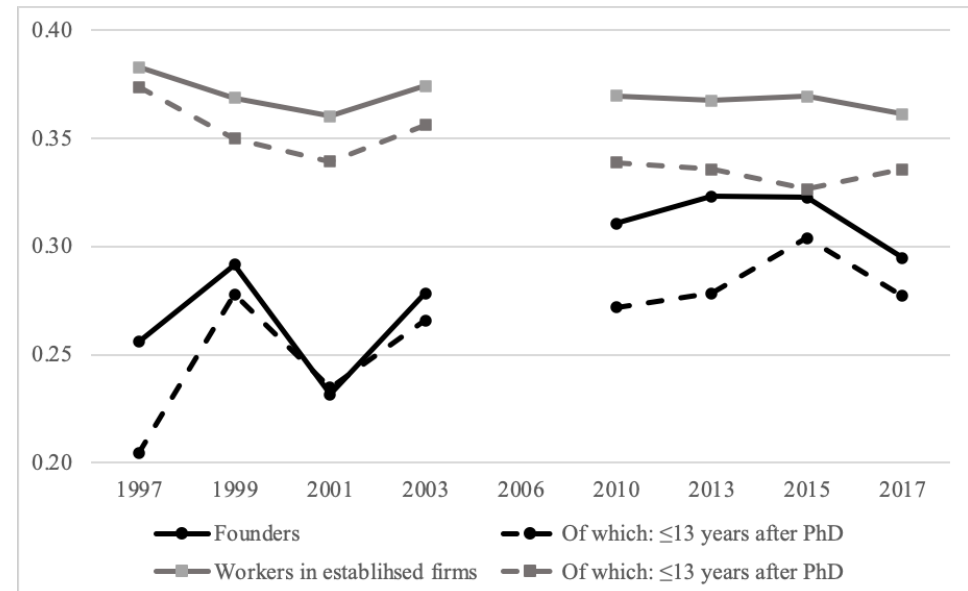

Source: Author calculations using weighted National Science Foundation data.

\section{H. Science-based PhD fields}

In this part we focus on areas that are especially dependent on prior cumulative knowledge. In our main analysis we control for 72 dummies for various occupation, but many founders list their occupation as "managers," which precludes further analysis. To obtain a proxy for those whose startups are likely to be especially dependent on cumulative knowledge, we use the SDR data on the field of the PhD. Specifically, we define as "science based" the following four broad fields of studies (variables MRMENG/NMRMENG in SDR surveys): biological sciences, environmental life sciences, chemical engineering, and electrical and computer engineering (dealing with hardware). Based on more detailed classifications, we also add the following narrower fields (variables MRMED/NMRMED in SDR surveys): bioengineering and biomedical engineering, petroleum engineering, biochemistry and biophysics, cell and molecular biology, and microbiological sciences and immunology. About a third of founders and a similar share of workers at established firms in our sample have degrees in these fields. We then repeat major parts of our analysis for science-based PhDs. (We also tried another definition that defined founders/workers who worked in occupations corresponding to the $\mathrm{PhD}$ fields above to be science based, adding managers with $\mathrm{PhDs}$ in sciencebased fields. The findings were similar to those presented here. Details are available upon request. We also tried a more inclusive definition that would combine the two. Again, the results were similar.) 
In Figure A11 we present the dynamics of the share of founders and workers employed at startups similar to Figure 1 for those with science-based PhDs. The picture is similar to Figure 1, but the decline in the share of startups is more precipitous (a decline of about 50 percent from 1997 to 2017). The decline in the share employed at startups is approximately the same as in Figure 1, suggesting that startup team sizes might be increasing, especially in this category.

Figure A11. Dynamics of the share of science-based PhDs employed at or founders of startups

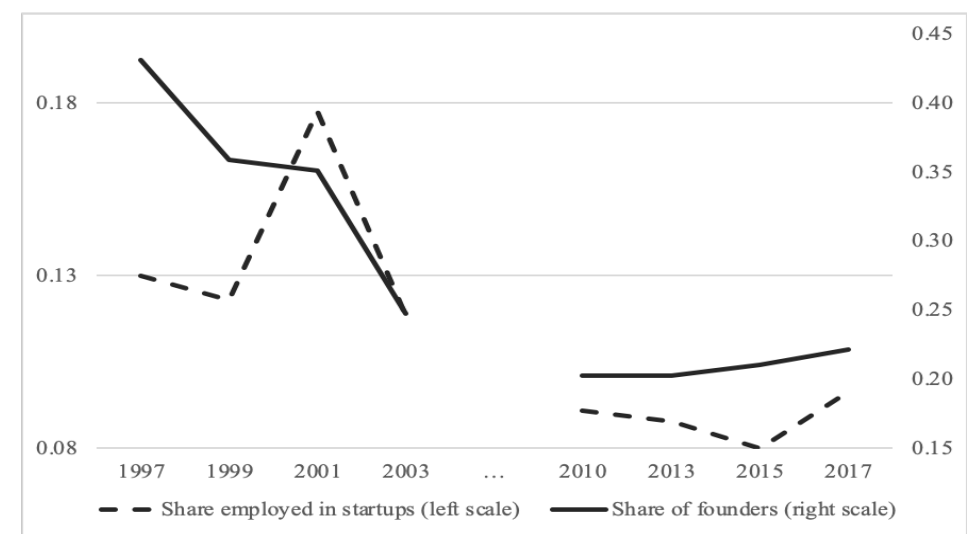

Source: Author calculations using weighted National Science Foundation data.

Table A10. Probability among science-based PhDs of being a founder

\begin{tabular}{|l|c|}
\hline \multicolumn{2}{|c|}{ DV: probability of an incorporated business owner being a startup owner } \\
\hline \multirow{2}{*}{ Time } & $-0.0172^{* * *}$ \\
\cline { 2 - 2 } Time squared & $(0.004)$ \\
\cline { 2 - 2 } Experience (years after PhD) & $0.0006^{* * *}$ \\
\hline \multirow{2}{*}{ Dummy set at one if a science-based PhD, zero otherwise } & $-0.00079^{* * *}$ \\
\hline \multirow{2}{*}{ Interaction term between time and the dummy set at one if a science-based PhD, zero otherwise } & $(0.000)$ \\
\hline \multirow{2}{*}{ Constant } & $0.0867^{* * *}$ \\
\hline & $-0.0048^{* * *}$ \\
\hline Other controls: gender, ethnicity, U.S. state of employment, occupations & $0.002)$ \\
\hline Observations & $0.576^{* * *}$ \\
\hline R-squared & Included \\
\hline
\end{tabular}

Estimation method: OLS, linear probability model. Robust standard errors in parentheses. ${ }^{* * *},{ }^{* *}$, and $*$ denote statistical significance at the 1 percent, 5 percent, and 10 percent levels, respectively.

In Table A10 we put this observation to a more formal test. The dependent variable is the probability of being a founder, with the sample consisting of all incorporated business owners, and the variables of interest are the time trend, work experience after $\mathrm{PhD}$, and a dummy set at one if the individual had received a $\mathrm{PhD}$ in one of science-based $\mathrm{PhD}$ fields and zero otherwise, as well as its interaction with the time trend. The estimations are carried out by a linear probability model, although probit and logit specifications lead to very similar results. 
The results in Table A10 indicate that over the past 20 years, the probability of being a founder has declined by about 20 percentage points $(-0.0172 * 20+0.0006 * 400)$ overall. This closely corresponds to what we saw in the raw data in Figure 1. Individuals with science-based PhDs were 8.7 percentage points more likely to be founders in 1997-again, very similar to the raw data. However, among individuals with science-based $\mathrm{PhDs}$, the probability of being a founder declines by an additional 0.5 percentage points each year, so that by 2017 they are indistinguishable from other $\mathrm{PhD}$ recipients in science and engineering. Overall, we see evidence here that the decline in startup entry rates is even more severe in science-based fields than in other fields.

Is this related to the burden of knowledge? To probe this, we once again look at the dynamics of $R \& D$ tasks as well as other tasks for science-based founders and compare them to their peers at established firms, shown in Figure A12, Panels A and B, following the same format as Figure 3.

Figure A12

Panel A. The number of all, R\&D, and management work activities among science-based founders

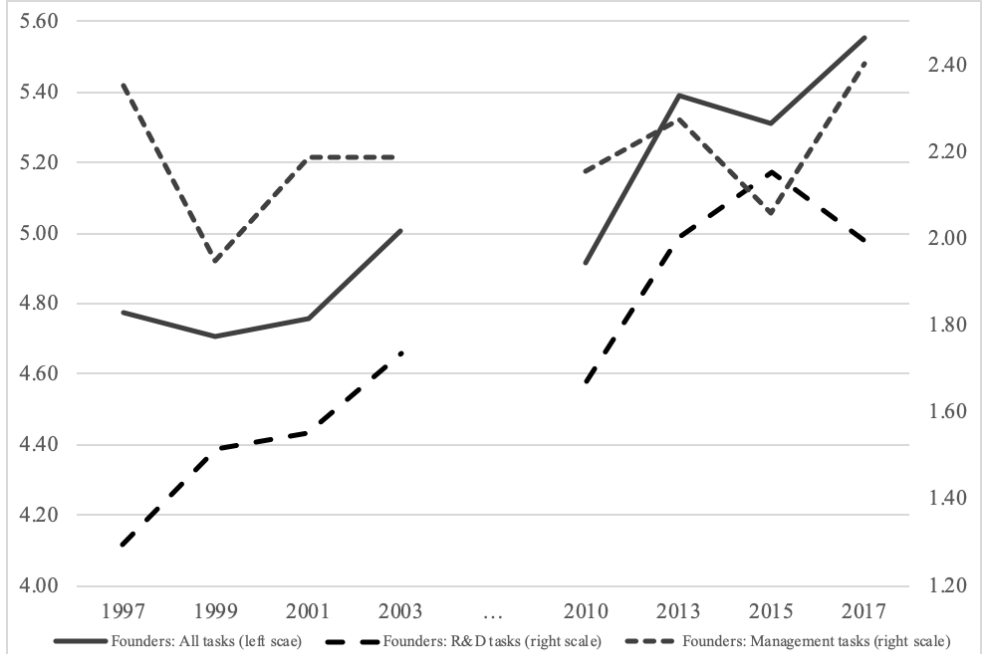

Panel B. The number of all, R\&D, and management work activities among science-based workers at established firms

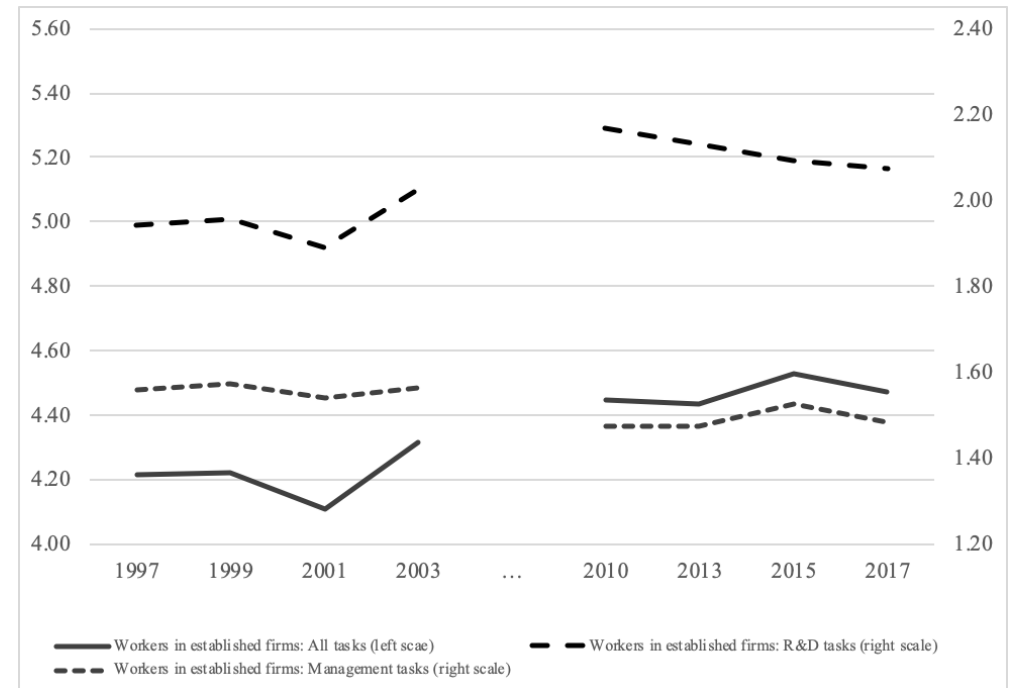

Source: Author calculations using weighted National Science Foundation data. 
Comparing Panel A of Figure A12 with the corresponding panel in Figure 3, we see that, first, perhaps not surprisingly, founders with science-based PhDs overall perform more R\&D tasks than other founders. They also experience a bigger absolute increase in the number of such tasks (from 1.3 to 2.0 between 1997 and 2017) compared to all $\mathrm{PhDs}$, although percentage-wise the rate of increase is similar, about 55 percent in both cases. As with all PhDs, their management tasks do not exhibit a time trend, leading to an increase in the overall number of tasks handled by founders from 4.8 to 5.6 in this sample ( 4.5 to 5.2 in the full sample). Thus, while time trends are similar between founders with science-based PhDs and other founders, the absolute burden of knowledge is significantly higher for the former than for the latter

The picture presented in Panel B, by contrast, does not reveal large differences between workers with science-based PhDs and workers with other PhDs at established firms, neither in the change in tasks nor in absolute levels. In particular, workers at established firms with science-based PhDs performed 1.94 R\&D tasks in 1997, and that number increased to 2.08 in 2017 (with a peak of 2.17 in 2010). the corresponding numbers for all PhDs were 1.86, 2.08, and 2.10 at the peak in 2015. The number of management-related tasks and other tasks is also very similar across these two samples for workers at established firms.

Another measure of the burden of knowledge suggested by Jones (2009) is age (work experience). In Table A11 we present the results of a regression analysis in which the dependent variable is the (IHS-transformed) number of years after $\mathrm{PhD}$, and the variables of interest are the time trend, a dummy set at one if the individual has received a $\mathrm{PhD}$ in one of the science-based $\mathrm{PhD}$ fields and zero otherwise, as well as its interaction with the time trend.

Table A11. Dynamics of founders' work experience

\begin{tabular}{|l|c|c|c|}
\hline & \multicolumn{3}{|c|}{ DV: IHS-transformed years after PhD } \\
\hline \multirow{2}{*}{ Time } & $0.0070^{* * *}$ & $0.0070^{* * *}$ & $0.0090^{* * *}$ \\
\cline { 2 - 4 } & $(0.003)$ & $(0.003)$ & $(0.003)$ \\
\hline \multirow{2}{*}{ Dummy set at one if a science-based PhD, zero otherwise } & & 0.0489 & 0.1251 \\
\cline { 2 - 4 } & & $(0.046)$ & $(0.083)$ \\
\hline $\begin{array}{l}\text { Interaction term between time and the dummy set at one if a } \\
\text { science-based PhD, zero otherwise }\end{array}$ & & -0.0061 \\
\hline \multirow{2}{*}{ Constant } & $2.4124 * * *$ & $2.4017 * * *$ & $2.3769 * * *$ \\
\cline { 2 - 4 } & $(0.350)$ & $(0.354)$ & $(0.359)$ \\
\hline $\begin{array}{l}\text { Other controls: gender, ethnicity, U.S. state of employment, } \\
\text { occupations }\end{array}$ & \multirow{2}{*}{ Included } & Included & Included \\
\hline Observations & 2,101 & 2,101 & 2,101 \\
\hline R-squared & 0.164 & 0.165 & 0.166 \\
\hline $\begin{array}{l}\text { Estimation method: OLS. Robust standard errors in parentheses. } * * *, * *, \text { and * denote statistical significance at the } 1 \\
\text { percent, 5 percent, and 10 percent levels, respectively. }\end{array}$
\end{tabular}

The average number of years after $\mathrm{PhD}$ for founders increases by about 0.7 percent with each calendar year, so founders are estimated to have about 14 percent more work experience after their $\mathrm{PhD}$, controlling for demographics, geographic location, and occupation in 2017 than in 1997. 
Interestingly, this does not translate into a much older age for founders (see Section 5.6 in the main text). If years after $\mathrm{PhD}$ is replaced by age in the regression in Table A11, the coefficient on the time trend drops to 0.0013 (statistically marginally significant), indicating that founders were, if at all, just 2.6 percent older in 2017 than they were in 1997.

Consistent with Jones (2009), we also see that founders with science-based PhDs tend to have more work experience after $\mathrm{PhD}$ than other founders, although the standard errors are high and the coefficients are not statistically significant at conventional levels. The issue appears to be the occupation dummies that offset the effect of science-based occupations in the estimations in Table A11. If we omit occupational controls, the coefficient on the dummy to capture science-based PhDs (not shown) doubles in magnitude and becomes statistically significant at the 5 percent level, indicating that founders with science-based $\mathrm{PhDs}$ tend to have about 10 percent more work experience than other founders. However, there is no pronounced trend toward founders with science-based PhDs becoming more experienced over time, suggesting that requirements for more post-doctoral work experience prior to becoming a founder increase more or less uniformly for all founders. Also consistent with the burden of knowledge theory, workers with science-based PhDs at established firms tend to have a larger span of control and more hierarchical depth than workers at other firms, but, once again, there is no trend toward either span of control or depth of hierarchy increasing over time for this category of workers compared to other workers. Details are available upon request.

\section{Supply of PhDs}

Figure $\mathrm{A} 13$ shows that the number of $\mathrm{PhDs}$ awarded in science and engineering fields increased approximately 45 percent, from 28,486 in 1997 to 41,294 in 2007.

Figure A13. PhDs awarded in science and engineering by U.S. colleges and universities, 1997-2007

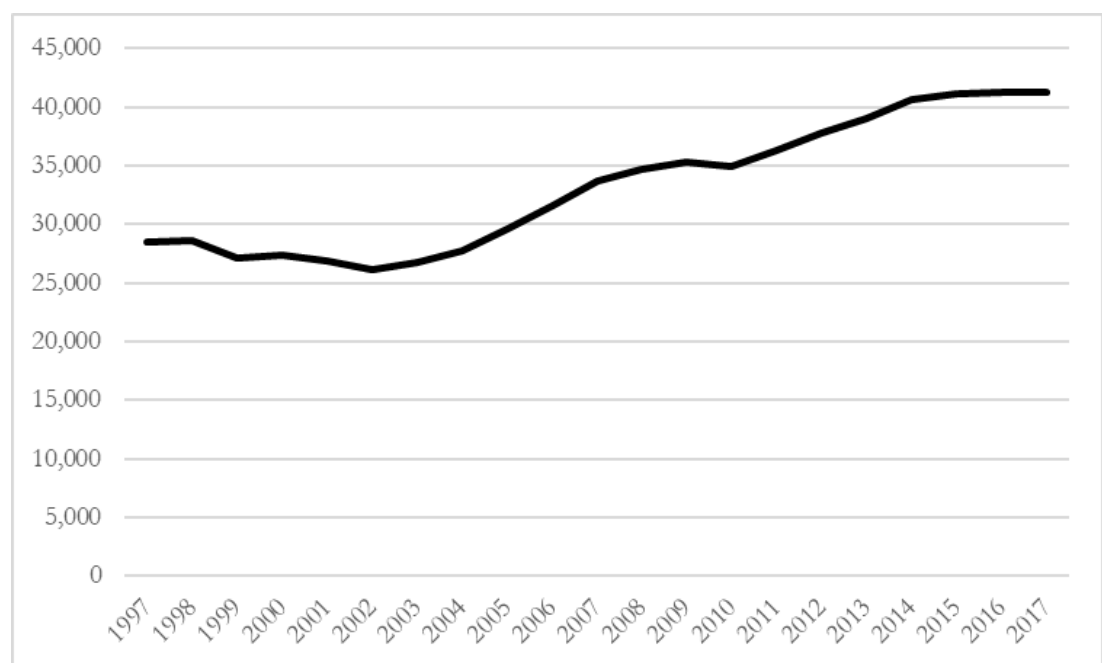

Source: Doctorate Recipients from U.S. Universities: 2018, National Center for Science and Engineering Statistics, National Science Foundation, available at https://ncses.nsf.gov/pubs/nsf20301/. 


\section{J. Computer/IT-related occupations and tasks}

The first year in which survey responses about new businesses become available is 1997, so we cannot verify directly whether the dot com boom of the late 1990s temporarily increased the propensity to found/be employed in startups above the long-term trend. We note, however, that other studies found that the trend toward declining business dynamism is long-term and while it may have been marginally influenced by the dot com boom of the late 1990s, the effect appears not that large (see, e.g., Figure 7 in Akcigit and Ates, 2019a). Furthermore, while computers and IT were no doubt becoming more used in the jobs that doctorate degree holders are likely to perform, most of the specialization of the doctorate recipients in our data are not in computer or IT-related areas.

To make sure that the basic trends toward declining rate of startups (and employment in startups) are not driven by the trends in computer/IT-related occupations or tasks, we have reconstructed Figure 1 while excluding all such occupations (computer and information scientists, system analysts, database and network administrators, computer software and hardware engineers, computer programmers, etc.) and also excluding those who reported that computer-related work activities (computer applications, programming, system development) occupied at least 10 percent of their time during a typical work week. The results are presented in Figures A14 and A15, respectively.

Figure A14. Dynamics of the share of PhDs employed in or founders of startups, excluding computer/IT-related occupations

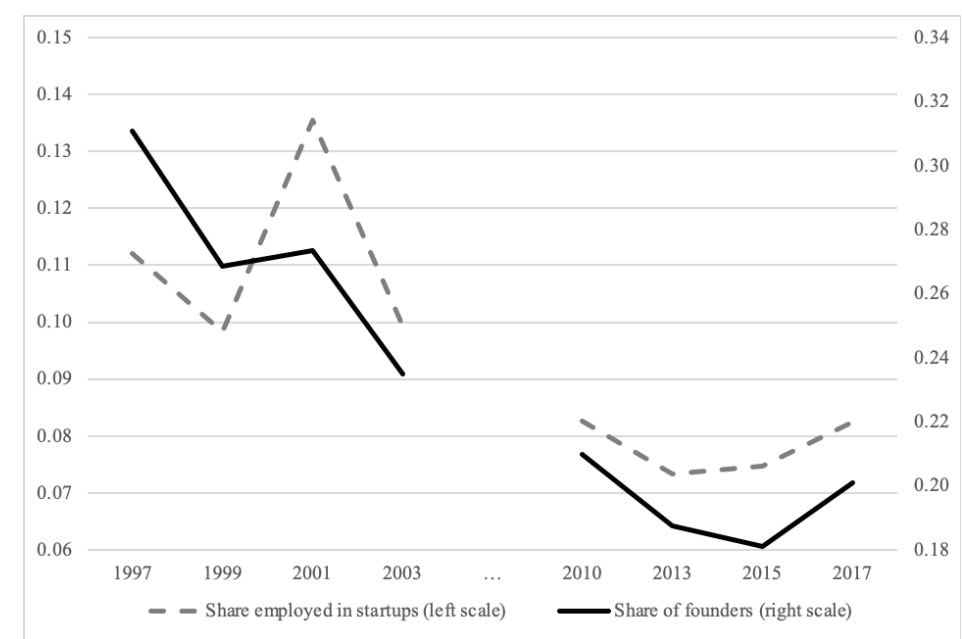

Source: Author calculations using weighted National Science Foundation data.

Both figures look almost exactly the same as Figure 1 in the main text. The rate of startups in computer-related occupations themselves (not shown) also fell over time, by about one half from the late 1990 s to the late 2010 s. 
Figure A15. Dynamics of the share of PhDs employed in or founders of startups, excluding computer/IT-related tasks

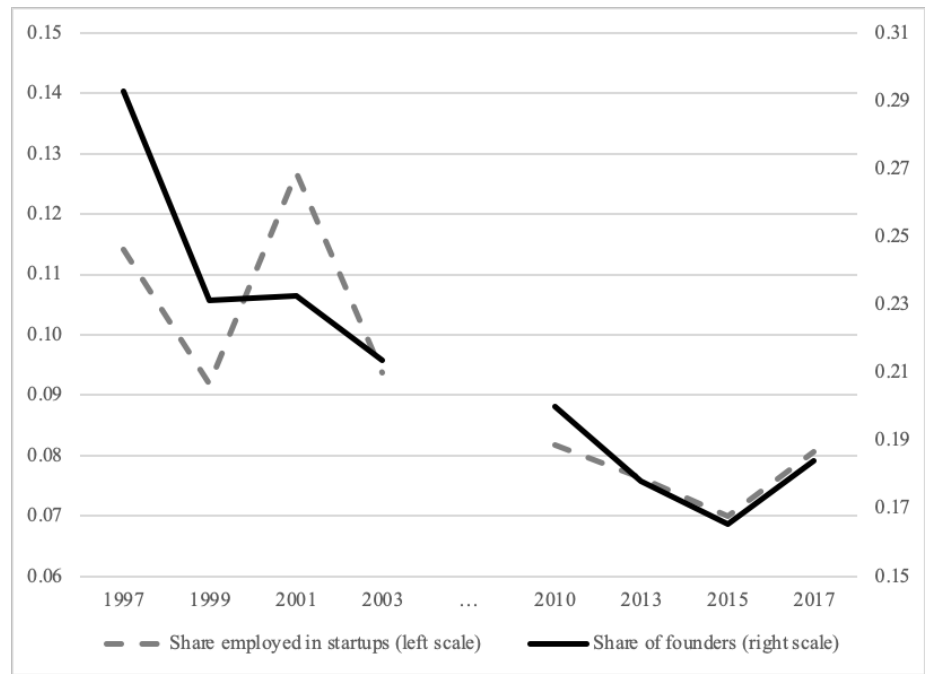

Source: Author calculations using weighted National Science Foundation data.

While the trend in startup founding rates and employment in startups is similar between computer-related and computer-unrelated occupations, the share of doctorate recipients who are employed in computer-related occupations in our data as a whole is steady among incorporated business owners and is actually even slightly increasing over time among those employed in the industry (Table A12). More precisely, there appears to be two periods where the latter fraction is increasing, from 1997-2001 and then once again, from 2008-2017. Significantly, there is no relation between these trends and the trend toward declining startups. The same is true of the dynamics of the share of PhDs performing computer-related tasks on their jobs.

Table A12. Share of PhDs in computer-related occupations and conducting computer-related tasks.

\begin{tabular}{|c|c|c|c|c|}
\hline & \multicolumn{2}{|c|}{$\begin{array}{l}\text { Share of PhDs in computer-related } \\
\text { occupations in total }\end{array}$} & \multicolumn{2}{|c|}{$\begin{array}{l}\text { Share of PhDs with computer-related tasks } \\
\text { in total }\end{array}$} \\
\hline & $\begin{array}{l}\text { Industry } \\
\text { employment }\end{array}$ & $\begin{array}{c}\text { Incorporated } \\
\text { business owners }\end{array}$ & $\begin{array}{l}\text { Industry } \\
\text { employment }\end{array}$ & $\begin{array}{l}\text { Incorporated } \\
\text { business owners }\end{array}$ \\
\hline 1995 & 0.099 & 0.051 & 0.418 & 0.314 \\
\hline 1997 & 0.128 & 0.076 & 0.401 & 0.299 \\
\hline 1999 & 0.150 & 0.070 & 0.427 & 0.317 \\
\hline 2001 & 0.156 & 0.058 & 0.412 & 0.291 \\
\hline 2003 & 0.138 & 0.070 & 0.375 & 0.295 \\
\hline 2006 & 0.132 & 0.068 & 0.314 & 0.238 \\
\hline 2008 & 0.125 & 0.067 & 0.324 & 0.230 \\
\hline 2010 & 0.140 & 0.049 & 0.348 & 0.236 \\
\hline 2013 & 0.148 & 0.062 & 0.355 & 0.233 \\
\hline 2015 & 0.156 & 0.064 & 0.364 & 0.239 \\
\hline 2017 & 0.167 & 0.064 & 0.392 & 0.258 \\
\hline
\end{tabular}

Note: PhDs with "computer-related tasks" are those who reported that computer-related work activities occupied at least 10 percent of their time during a typical work week. 